\title{
Powerless, With a Guitar": Music and Student Protest at the University of Iowa, 1965-1971
}

\author{
Taylor Finch
}

The year 1965 marked a turning point in American history. In Selma, Alabama, Martin Luther King Jr. led civil rights demonstrators on a march pushing the passage of the Voting Rights Act of 1965. In Vietnam, the war escalated, as President Johnson instituted continuous air strikes known infamously as Operation Rolling Thunder and deployed 189,000 American ground troops into the country. In Washington, D.C., Students for a Democratic Society (SDS) organized the first major anti-war demonstration. In Newport, Rhode Island, Bob Dylan plugged in his electric guitar and shocked the nation as he left the folk protest movement behind. And, in Iowa City, Iowa, a sophomore engineering student named Steve Smith stepped onto a soapbox and lit a match.

"I feel," Smith said as he looked over a crowd of about 200 in the Iowa Memorial Union, "that now is the time, because of my own sense of dignity, my own sense of morality, to burn my draft card." 1 The flame, the first in the nation to engulf a draft card as a deliberate act of protest on a college campus after the act was illegalized, soon spread beyond Smith's careful act of nonviolence. It sparked in the meetings of the university's Students for a Democratic Society chapter in the IMU. It spread to a faction of the artists, writers, film makers, and musicians of Iowa City. It burned in the offices of

${ }^{1}$ Paul Butler, "U of Iowa Student Burns Draft Card During Soundoff," The Daily Iowan, October 21, 1965. Student Protest Vertical File, University of Iowa Special Collections.

Faculty Advisor: Dr. Landon Storrs, Department of History, the University of Iowa.

Copyright (C) 2016 Taylor Finch 
University faculty and in the student dormitories. It spread across campus: to the Pentacrest, the university president's home, the library, the Old Capitol building, the bars downtown, and the police station. The flame eventually engulfed the university's Old Armory and the Iowa City Civic Center entirely. The rise of student protest ignited a fire on campus that started out hopeful but soon became desperate and militant before smoldering away altogether. In its wake, it left a scorched trail of bitterness, distrust, and the ashes of a failed revolution.

The rise and decline of student protest at the University of Iowa began with the burning of Smith's draft card in 1965, hit its high points in the protests of 1967 and 1970, and fizzled out after a backlash against its violent tactics in 1971. Several student groups, most notably Students for a Democratic Society and the New University Conference (NUC), formed the backbone of these protests. Their influence spread to specific student and faculty demographics, such as the Writers' Workshop, the Center for New Music, and eventually, underground groups which published alternative newspapers like Middle Earth (1967-68) and The Iowa City Oppressed Citizen (1970). As the aim of student protest evolved from a grand declaration of peace in Vietnam, to national revolution, to outright revolt against the local university administration, an ever-changing undercurrent of music not only was used as a tool of the protestors, but also captured the spirit of a movement whose motivations and implications, both political and social, we struggle to define concretely even today.

Mickey Hart, drummer of the famous psychedelic jam band The Grateful Dead, once said, "We're not the whole event, but we're what the event sounds like." 2 At face value this might seem frivolous. Does the music of such a movement really carry political, social, or historical impact? Culture, while an important historical marker, is difficult to measure. It offers a less concrete analysis than quantitative data or official documents. However, in the context of the student movement of the Sixties and Seventies, culture-more specifically, music - is essential to the narrative. The music of the period offers insight into the ideology of student protest and, at the time, often amplified student voices for a broader audience. The music is also an example of how culture often remains one of the last vehicles of a movement's voice long after that movement has died. For these reasons, Hart's sentiment speaks to the role

2 The History of Rock N’ Roll, directed by Andrew Solt (1995; Burbank, CA: Time-Life Video), DVD. 
music played in student protest at the University of Iowa. The recordings, writings, and stories of musicians and artists active in the Iowa City scene offer insight into the ideologies, voices, and messages of the student movement. As the protest movement shifted from nonviolence to militancy and from global revolution to local revolt, the genre, message, setting, and role of rock music that was being consumed and produced in Iowa City shifted as well.

This shift was not unique among student protests movements in the United States. In fact, the narrative of student anti-war demonstrations in Iowa City can serve as a case study representing the majority of 1960s-1970s student protests across the country. At the University of Iowa, just like New York University, the University of California at Berkeley, and Kent State, the shift from nonviolence to open rebellion led the movement to destroy itself. As Harvard student Steven Kelman wrote in 1970, "These students are the victims of a self-imposed and self-perpetuating isolation, scornfully viewing almost all but themselves as 'conned' into contentment with all aspects of present-day American life. Their tactics deepen their isolation, and their haughtiness turns ordinary people away from them." 3 While Kelman was clearly inclined to hostility toward protestors, his words serve as an example of the bitterness the rest of the country began to feel toward radical demonstrators. This bitterness, coupled with fissures in the movement based on protest tactics, viewpoints of race and gender, and the rise of drug use, spelled the end of student protest at Iowa. Slowly, the students abandoned the methods of nonviolence and civil disobedience in favor of completely dropping out of a society that they could not change. What remained was a conservative backlash against all student radicals, a confused legacy of an originally-hopeful movement tinged with drugs and violence, and the music that captured it all.

\section{Eve of Destruction: The Origins of Iowa Student Protest, 1965- 1966}

Think of all the hate there is in Red China, Then take a look around to Selma, Alabama.

You may leave here for four days in space,

But when you return it's the same old place -

The pounding of the drums, the pride and disgrace.

${ }^{3}$ Steven Kelman, Push Comes to Shove: The Escalation of Student Protest (Boston: Houghton-Mifflin, 1970), 5. 
You can bury your dead but don't leave a trace.

Hate your next door neighbor but don't forget to say grace.

\section{Eve of Destruction, Barry McGuire 1965}

This stanza of Barry McGuire's anthem of protest paints a telling picture of the glaring hypocrisies and paradoxes that were present in American society in 1965. The inconsistencies of a government that sought 'freedom' in Vietnam while still denying its black citizens voting rights and preached 'morality' while disproportionately conscripting its youth into what many saw as an immoral war were most glaringly obvious to those under the age of 30. At the University of Iowa, a surge of admissions and a new president who wanted to see more programs for women and ethnic minorities set the stage for a demographic of students who felt that they could make a difference. Similarly, the national pressures of the draft and the creation of Students for a Democratic Society influenced student life on campus. Many of the students who began to organize in Iowa City were members of the outer reaches of campus society, namely artists, dancers, writers, and musicians. These artistic groups were more inclined to socialize and collectively think amongst themselves. This not only alienated them somewhat from the rest of their peers, but also drew outside artists and free-thinkers, many of whom were not students, into the art scene and protest movement. Influenced by nationally acclaimed musicians who were writing about what they saw, this demographic of Iowa City youth began to create its own society whose music and art would both reflect and influence the rise of student protest.

On December 5, 1964, Howard R. Bowen was sworn in as the fourteenth president of the State University of Iowa. In the beginning of his term, Bowen, noting the unprecedented rise of post-war baby boomers reaching college age and the increase in disposable family income, predicted that the university's student body would double in size by 1980 . His hunch was fairly accurate, and in the first five years of his administration university enrollment rose from 14,500 to $19,500 .{ }^{4}$ Bowen, however, was discouraged by the disproportional number of white, male students to that of female students and students of color. To combat this, Bowen oversaw the creation of a University Committee on Human Rights, the hiring of a counselor for minority students, and the solicitation of a Martin Luther King, Jr. Scholarship Fund, an Afro-American

${ }^{4}$ Stow Persons, The University of Iowa in the Twentieth Century: An Institutional

History (Iowa City: University of Iowa Press, 1990), 179-181. 
Studies Program and an Afro-American Center. While encouraging that "positive steps be taken to increase the number of women students," as historian Stow Persons puts it, and appointing a single counselor for all minority students on campus were hardly revolutionary measures, the University of Iowa was certainly on its way to a more comprehensive, diverse student body than ever before. ${ }^{5}$ In order to cement the university's new brand, The State University of Iowa dropped the word "State" from its title and undertook an unprecedented era of construction. Five new dormitories, nine new buildings (including the Hancher Auditorium, the English-Philosophy Building, Phillips Hall, and Van Allen Hall), and new additions to the Main Library, Biology Building, and the University Hospital were all constructed during this period. ${ }^{6}$

The post-war baby boomers who flocked to the university were increasingly aware of the injustices running rampant through American society-injustices which seemed to be largely accepted or ignored by the majority of citizens. The recently reformed and rebranded University of Iowa put students in new positions to effect change. Out of the rising African American student demographic and politically-conscious student ideology came a push for Iowa student activism in the struggle for civil rights. In 1965, a small group of students organized a civil rights march and hunger strike in front of the Iowa City Post Office to raise awareness of the injustices faced by black workers in Selma, Alabama. ${ }^{7}$ Among these eight students was Steve Smith. Smith had been part of a group of students who traveled to Mississippi in 1964 as part of 'Freedom Summer,' a movement spurred by the Student Nonviolent Coordinating Committee (SNCC) that intended to register African Americans in the Deep South to vote. While in Canton, Mississippi, Smith was arrested and brutally beaten by police officers for his efforts. ${ }^{8}$ Smith later said, according to the Cedar Rapids Gazette, that "he had gained respect during that time for nonviolent resistance, and added that his first exposure to the Vietnam issue was during his work with SNICK [sic]."9 Smith's experience exemplified a

${ }^{5}$ Persons, The University of Iowa in the Twentieth Century, 182.

${ }^{6}$ Ibid., 184.

7"Iowa Engineering Student Burns Draft Card," Cedar Rapids Gazette, October 21, 1965, Student Protest Vertical File, University of Iowa Special Collections.

${ }^{8}$ David McCartney, "Old Gold: Steve Smith, following his conscience," Iowa Now, July 30, 2012, accessed April 16, 2015, http:// now.uiowa.edu/2012/07/old-goldsteve-smith-following-his-conscience.

9 "Iowa Engineering Student Burns Draft Card," Cedar Rapids Gazette, 2009, Student Protest Vertical File, University of Iowa Special Collections. 
broader phenomenon, as many students and organizations began to refocus the efforts and energies they had devoted to civil rights activism toward Vietnam War resistance.

The draft became the fastest-growing consciousness issue among youth in the United States in the latter half of the Sixties for one simple reason: it affected nearly everyone. After the Selective Service Act of 1948, every male in the United States between the ages of eighteen and twenty-six was required to register for the draft through the Selective Service System, which could call upon them to serve in the armed forces (in peacetime or in wartime) for a period of twenty-one months. ${ }^{10}$ The draft did not have such an infamously direct relationship with the Vietnam War until around 1965, when President Johnson escalated the war, increasing the number of ground troops and instituting bombing raids and other offensive measures, such as Operation Rolling Thunder.

The growing resistance to the draft highlighted the widening generation gap between the post-war baby boomers and their parents. Steve Smith's father, a disabled World War II veteran, publicly voiced his disappointment in his son by sharing his distaste for draft resistors in local newspapers just days after the younger Smith burned his draft card. He was not alone in his perception of a spoiled generation unwilling to die for its country. Iowa Republican legislator William Scherle told the Cedar Rapids Gazette, "Most of the student demonstrators are based primarily in the age group that is eligible for the draft. I wonder sometimes if they think this demonstrating will get us to pull out of Vietnam so that they wouldn't have to serve. If I were on the front lines, I wouldn't want these people serving next to me."11

Students who actively resisted the draft, however, did not see their act as one of cowardice. Rather, they claimed to be speaking out against a war that was ignorant, immoral, and motivated by an American imperialist ideology. The 'us vs. them' anti-communist mentality that so many Americans used to justify the war seemed tragically simplistic to a generation who had grown up under the shadow of the atom bomb and taught to fear a 'red menace' that never seemed to manifest itself. "The whole reasoning behind anticommunism and revolutions I can't swallow," Smith said. "I don't see revolutions being started by communists. People [in Vietnam] are being

\footnotetext{
10 Selective Service Act of 1948, 50 U.S.C. \ 451-473 (1948).

11 "Iowa Engineering Student Burns Draft Card."
} 
suppressed and denied their right to enough food and proper housing." 12 Furthermore, the U.S. government was not only forcing young Americans to fight in a war many did not believe in, but also deliberately targeting economic and ethnic minorities for conscription. In the first few years of the Vietnam draft, undergraduate and graduate college deferments were offered to potential draftees. However, for impoverished young men (often of color, as institutionalized racism kept most black and brown Americans in society's lowest economic classes), college was not an option. Furthermore, in 1966 the U.S. lowered the acceptable intelligence score for conscription to $15 \%$ or higher, which further punished impoverished and, therefore, largely uneducated Americans. ${ }^{13}$

This case of socio-economic discrimination in the draft system lent a noble but somewhat condescending air to the efforts of white collegiate students against the draft. As Michael S. Foley writes, "Although draft resisters successfully sought to expose the inequities of the Selective Service System, the same system that sent a disproportionate number of working-class and minority men to fight in Vietnam, the draft resistance movement never attracted significant numbers of men from those groups." 14 The anti-draft movement was largely propelled by middle-upper-class groups like Students for a Democratic Society, who addressed this issue in the first line of their manifesto, the Port Huron Statement. "We are people of this generation, bred in at least modest comfort, housed now in universities, looking uncomfortably to the world we inherit," they wrote. ${ }^{15}$

For SDS, there was a definite distinction between draft dodging and draft resisting. They based this distinction on the idea that those who dodged the draft by obtaining faked medical deferments or crossing the border to Canada were selfishly motivated, since someone would have to take their place on the linemost likely someone of color or of low economic standing. Smith's draft card burning served rather as a concrete example of active draft resistance, as he

12 The Daily Iowan, January 5, 1966, Student Protest Vertical File, University of Iowa Special Collections.

${ }^{13}$ Michael S. Foley, Confronting the War Machine: Draft Resistance During the Vietnam War (Chapel Hill, North Carolina: The University of North Carolina Press, 2003), 1012.

${ }^{14}$ Foley, Confronting the War Machine, 25.

15 "The Port Huron Statement," in Vandals in the Bomb Factory: The History and Literature of Students for a Democratic Society, ed. G. Louis Heath (Metuchen, N.J.: The Scarecrow Press, 1976), 216. 
cited his reasons as moral ones. While he admitted that he burned his card in violation of the law, he argued that the law violated the free-speech provision of the U.S. Constitution and international human rights law. ${ }^{16}$ SDS was equally committed to using the university setting as a basis for educating and encouraging activism on the issues of race, the war, and the draft. As Smith said, “The campus doesn't really deal with the problems of society as far as curriculum is concerned. There have been a lot of movements to end the war and to aid civil rights, but any attempt has been largely extracurricular. If the university doesn't deal in some way with the function of society, then its function is not education, it's training." 17 When it was officially recognized by the Student Senate in 1965, SDS at the University of Iowa sought to raise awareness for the anti-war effort and reform the general curriculum. ${ }^{18}$ This seemingly temperate ideology would warp with the passage of time and the escalation of the free speech and draft resistance movements, but even in 1966, SDS's motto remained "build, not burn." 19 This mantra did not refer to the burning of draft cards, of course. Rather, SDS aimed to build a strong, collective, and meticulously organized infrastructure of peaceful activists who would gradually expose injustices within the system even as they worked to eradicate them.

As the student consciousness movement at the University of Iowa slowly came into being around 1965, it was mirrored by a sister-movement within the avant-garde community. Just as SDS and civil rights activist groups at the university were based on a national model of organization, so too did the music scene of Iowa City take its cues from more visible movements. In 1965, music was on the precipice of a great fusion between politically conscious folk and chart-topping blues/pop. Up until this point, the majority of politically conscious writing came from the school of folk and was represented by artists such as Bob Dylan, Joan Baez, Tom Paxton, and Phil Ochs. These artists, many of whom were students or were influenced by the student movement, wrote songs in the folk style - with politically provocative lyrics and the accompaniment of a single acoustic guitar. Notably, just as SDS was largely represented by a group of white student activists, the political folk resurgence

\footnotetext{
16 Des Moines Register, November 3, 1965, Student Protest Vertical File, University of Iowa Special Collections.

17 The Daily Iowan, January 5, 1966, Student Protest Vertical File, University of Iowa Special Collections.

${ }_{18}^{18}$ Persons, The University of Iowa in the Twentieth Century, 194.

${ }^{19}$ Kelman, Push Comes to Shove, 105.
} 
also came from a drive of equality for the 'underdog' in American society as spurred by privileged, white students. Because of the artists' comfortable status in a society that was harsh to ethnic and economic minorities, the movement could be perceived as patronizing. Nonetheless, the musicians acted from a sense of social justice- one more compassionate than the standpoint of many of their white peers. Several of these artists, including Joan Baez and Bob Dylan, lent their talents to the civil rights movement, participating in Freedom Summer and performing at the March on Washington in 1965. As the war escalated, folk singers developed a musical consciousness against what they felt was an immoral war conducted by an authoritarian regime. Taking a cue from the father of folk, Woody Guthrie, whose guitar famously read "This Machine Kills Fascists," folk artists wrote songs like "The Universal Soldier," "Draft Dodger Rag," and "Eve of Destruction." Phil Ochs penned the most famous of these anthems, "I Ain't Marching Anymore," which called upon youth to raise their voices against a society that so readily accepted war and a regime that benefited from bloodshed:

It's always the old to lead us to the war.

It's always the young to fall.

Now look at all we've won with the saber and the gun -

Tell me is it worth it all?

For I flew the final mission in the Japanese sky,

Set off the mighty mushroom roar.

When I saw the cities burning I knew that I was learning

That I ain't marching anymore.

Now the labor leader's screamin'

When they close the missile plants.

United Fruit screams at the Cuban shore.

Call it peace, or call it treason.

Call it love, or call it reason -

But I ain't marching anymore. ${ }^{20}$

Simultaneously, British Invasion bands like The Beatles and the Rolling Stones were making rock \& roll the popular music of the time. In 1965, when Bob Dylan switched from traditional folk music to electric rock at the Newport

20 Phil Ochs, I Ain't Marching Anymore, CD (London: Elektra Records 1965). 
Folk Festival, he integrated the two genres. After 1965, the Beatles began to create more conceptual albums, such as Rubber Soul and Revolver, which revolutionized the music industry by focusing on entire albums rather than on singles written for the market. The popular music market was characterized by singles aimed at teenagers, often girls, and usually with themes about love or heartache. The Beatles' early career was characterized by these 'bubble-gum' tunes, and it was the very appeal of these market-friendly songs that helped make the Beatles the biggest pop act of the century. However, influenced by the building consciousness of the youth movement and the rise of drug experimentation, the group eventually used its pedestal to bring more experimental and conceptual albums to the forefront of popular music. The new concept of 'free' and 'experimental' music combined with the consciousness of folk to create entirely new genres, and countercultural scenes began to grow up around them. While these concepts were not necessarily antiwar or politically resistant, they were culturally resistant to musical genres enjoyed by the previous generation, and were thus revolutionary in a unique way.

All of these schools of musical expression existed in Iowa City around 1965, though they struggled to find their outlet. While the internationally famous Writers' Workshop encouraged an influx of free-thinkers, Iowa City seemed to lack venues where they could implement their ideas musically. As musician Patrick Hazell, who formed the Mother Blues Band in Iowa City in the 1960s, recalls, "Iowa City was really, really, really dead with live music, except for three bars downtown. There was a place called Kenny's, one called Donnelly's, and one called Li'l Bill's. That's where the artists all went."21 Musicians who performed at Li'l Bill's were mostly blues artists, like The Prophets, who formed in Iowa City before moving to San Francisco's Haight-Ashbury scene to further explore countercultural forms in the late 1960s. However, blues was not the only music form present in Iowa City. In 1962, Keith Dempster opened The Mill downtown. "It started out as a poetry reading spot," Hazell says. "It was a coffee house originally. He would have some folk singers play there or something. That was back in the days when they were doing hootenannies." 22 'Hootenannies,' originally conceived of by folk legend Pete Seeger, were group concerts where several performers and audience members all contributed to the music being played and sung. A purely folk-based invention, 'hootenannies'

${ }^{21}$ Patrick Hazell, interview by Taylor Finch, March 25, 2015, Washington, IA.
22 Ibid. 
would later be used at University of Iowa student protests to encourage activist participation and a collective voice.

Because not many music venues existed in downtown Iowa City at the time, Li'l Bill's and The Mill were instrumental in cultivating a collective presence among musicians, artists, film-makers, and writers. "Keith Dempster was the glue that held the music scene together," Diane Troyer recalls. Troyer was a member of the undergraduate Writers' Workshop in the late 1960s, as well as a film maker and a war widow. 'It's not just all about the music... It's the art that's going on simultaneously," she stresses. ${ }^{23}$ It's equally important to note that this music and art was not part of the 'hippie' movement, which really was not defined in the U.S. until 1967 or 1968. Iowa City in 1965 was an intellectual, avant-garde scene. "The scene was really tight," Hazell explains, "so when the bars closed somebody would say, 'Oh, there's a party at 936 Gilbert' or some address. Word would spread quickly and everybody would go to this place. It would be all the poets, painters, musicians, and the dancers. A lot of real avantgarde stuff." 24

The evolution of the tight-knit music scene was further influenced by the founding of the Center for New Music in 1966. Hazel explains, "They transferred a core of musicians from the University of Illinois, which had a very well-known music department of avant-garde composers and so on. This was all part of the concept of 'free music,' which was totally improvised music that not a lot of people were doing. This was revolutionary, in a way." 25 The Center for New Music provided an outlet for experimental musicians in Iowa City, while the Writers' Workshop also influenced the ideas and concepts the musicians were writing about. In fact, two brothers used the Writers' Workshop to found the Paper Place, which published underground press and avant-garde works of students. ${ }^{26}$

This collective of artists, musicians, and free-thinkers began to influence aspects of student thought on campus. Not all students were anti-war or even interested in political activism, but a distinct demographic was beginning to define itself. This new form of thought was driven by the community of beatniks who spread their ideas through their writing and music. However, this community did not always agree on politics or the way to effect local or national

${ }^{23}$ Diane Troyer, interview by Taylor Finch, September 25, 2015, Iowa City, IA.

${ }^{24}$ Hazell interview.

25 Ibid.

26 Ibid. 
change. "All these people of all types—genders, and, you know, color, and everything else-it was a pretty happening scene. But it was on the edge, definitely a violent edge," Hazell points out. The so-called "violent edge" upon which the student movement teetered in 1965 would become sharper and more focused by 1967.

\section{Masters of War: The Escalation of Iowa Student Protest, 1967}

Come you masters of war -

You that build all the guns,

You that build the death planes,

You that build all the bombs.

You that hide behind walls,

You that hide behind desks -

I just want you to know

I can see through your masks.

How much do I know

To talk out of turn?

You might say that I'm young.

You might say I'm unlearned.

But there's one thing I know,

Though I'm younger than you -

Even Jesus would never

Forgive what you do.

\section{Masters of War, Bob Dylan 1963}

Though the song "Masters of War" was released four years before student protest truly escalated at the University of Iowa, the lyrics speak to the attitudes that many of the protestors shared. This attitude was not only against a national administration that was perpetuating a bloody war, but also the university that was allowing these "Masters of War" to recruit students on campus. The year 1967 became a volatile one, and a turning point in student relations with the anti-draft movement, their own liberal beliefs, and the university administration.

By 1967, new players in the game invented new rivalries and new ideologies. SDS and other student activist groups became increasingly upset with what they saw as University of Iowa complicity in the Vietnam War, and so they 
began to target the university as a tool of the corrupt U.S. system. Now, instead of simply raising educational awareness, the protest movement came to believe that local change could incite national and then global revolution. This revolution, they believed, was to be nonviolent and propelled by civil disobedience. Student activists organized protests obstructing recruiters at the university from organizations who they felt were complicit in the war in Indochina. However, when the university attempted to police these protests, the violent edge sharpened. The small group of students who had originally believed in revolution through song, collective voice, and nonviolence used university disciplinary measures as justification for new ammunition against authority.

Student voices became more important than ever, and were published underground in the newspaper Middle Earth. Though they were a small student and civilian collective, the protestors slowly began to gain support due to their commitment to, and knowledge of, the movement. This is evidenced not only by the creation and circulation of Middle Earth, but also by the rise in the number of protests and participants in 1967. A few of that year's demonstrations boasted upwards of 200 student activists. While this still remained a very small demographic of the student body, it was much bigger than Smith standing alone on a soapbox. Student voices in support of the growing movement were published in an early edition of Middle Earth. "For too long the biased views of the god and country hypocrites have overshadowed the truth," read one editorial. "These truths can now be expressed freely... Middle Earth, you've arrived, and may you live forever." 27 Another letter of praise was sent to the paper from some students in Burge Residence Hall: "Bravo. Bravo. Bravo. The inmates of Burge Hall wish to commend you on a job well done. Shantih, shantih, shantih. Love." 28 As Bob Dylan pointed out in "Masters of War," student radicals were not the young, naïve fools that many counter-demonstrators portrayed them as. Rather, they had begun to see further into a governmental hierarchy and administrative system that they believed was corrupt not only at the highest levels, but all the way down to the universities and local authorities.

${ }^{27}$ Middle Earth 1, no. 3 (1967), Underground Publications, University of Iowa Special Collections.

28 "Shanti" is a Sanskrit word for inner peace or bliss. The "inmates" of Burge Hall spelled the word "shantih" in reference to T.S. Eliot's poem The Waste Land, in which the poet defined "shantih" as "The Peace which passeth understanding"; Ibid. 
At the university level, students began to feel as though the institution that reared them was just another pawn in this corrupt government. Much of this disillusion sprung from the capitalist practices of the university and its cooperation with large corporations. In a campus speech charging the university with complicity in the war, student Lory Rice dismissed as "noble, hypocritical phrases" the university's claims that it served the interests of students, the people of Iowa, "Truth," and democracy. The university in fact was merely an "obliging prostitute" serving the interests of corporations, with students and faculty "being screwed by the big corporations and their guardian and mediator, the U.S. government." 29

The transcript of this speech was subsequently published in Middle Earth. The publication (whose name was inspired by J.R.R. Tolkien's Lord of the Rings Trilogy, which came to be a symbol of the counterculture) ${ }^{30}$ laid out the movement's new plans for revolution. "Middle Earth is a community of the mind... The point is activism: the famous liberal rhetoric that goes on in the letters of the editor columns is what we are not. Middle Earth says that a story in print is not enough - if we don't act as if it made a difference to us," they published in their third issue. ${ }^{31}$ Fed up with traditional reporting on student activism, Middle Earth took the reporting into its own hands. "We are postbomb and that clarifies a lot of things for us. That's why we can't dig the same things that everybody thought made the world go round. But there are other voices, other mind-waves that T.V. doesn't pick up. That's why Middle Earth." 32

The writers of Middle Earth and their supporters within the artistic community in Iowa City not only broke with traditional press, but also with the principles that had been guiding student activism until 1967. They based their new philosophy on three principles: the incitement of a revolution, the alienation of liberals, and nonviolent civil disobedience. They were careful to maintain, however, that their nonviolent revolution was not one of an oppressed people. Student activists were still privileged, mostly white youths. However, they did not pretend to face the same insurmountable problems and

${ }^{29}$ Lory Rice, “A Speech Given at the Anti-Dow Rally February 14," Middle Earth 1, no. 11 (1967), Underground Publications, University of Iowa Special Collections.

${ }^{30}$ Many of Led Zeppelin's songs, like "Misty Mountain Hop" and "Ramble On," contained references to the saga, which helped cement its countercultural influence.

${ }^{31}$ Dave Miller, “Letter to Readers," in Middle Earth 1, no. 3 (1967), Underground Publications, University of Iowa Special Collections.

32 Ibid. 
oppression that their fellow revolutionaries faced around the world. "We want a revolution, and we want it now," they wrote. "But it is not a revolution of the kind that Castro fought or the NLF is fighting. We are not starving nor are we disenfranchised. Our suffering is not that of physical anguish and pain that makes guerillas, but the mental torment of seeing the forces of inhumanity and insanity working their will unchecked." 33

They also felt secure in their decision to alienate American liberals, who they felt were hypocritical and not doing enough for the revolution. As one Middle Earth editorial explained, liberal faith in "all those beautiful 'democratic' procedures" was simply naive. No one would be happier than the radicals to find that the liberals were right, for then they could retire from activism and "return to peacetime work." But the "corruption of the press, the brutality of the police, [and] the hypocrisy of our elected 'representatives"' made this an unlikely outcome. The "democratic virtues" touted by liberals had long since been undermined by press corruption, police brutality, and "the hypocrisy of our elected 'representatives' ... the most brutal expression of which is still the Vietnamese War." 34 New student radicals felt that liberals had become old, crooked, and bitter. Liberals felt that change could happen within the system, while radicals felt that change would only come with a complete overhaul of the system. Musicians and artists reflected these ideas in much of their work. Most notably, "Love Me, I'm a Liberal" by Phil Ochs captured the bitterness radicals felt towards liberals by mocking the differences between what liberals said and what they did:

I go to civil rights rallies,

And I put down the old D.A.R.

I love Harry and Sidney and Sammy.

I hope every colored boy becomes a star.

But don't talk about revolution!

${ }^{33}$ NLF refers to the National Liberation Front, which fought to liberate and reunify North and South Vietnam.

“Where Do We Go from Here?” Middle Earth Vol 1, no. 7 (1967), Underground Publications, University of Iowa Special Collections.

34 "Our Present Fight: What it is About, its Conditions, and Where it is Leading," Middle Earth 1, no. 7 (1967), Underground Publications, University of Iowa Special Collections. 
That's going a little bit too far.

So love me, love me, love me. I'm a liberal. ${ }^{35}$

The third principle of the radical student revolution rested on nonviolent civil disobedience. However, that principle proved harder to maintain once student protest began to explode at the University of Iowa in 1967. The large majority of protests that took place on campus during this year were organized sit-ins against recruiters from outside organizations complicit in the war effort. The first of these occurred as early as January, when a CIA agent attempted to recruit students on campus. In a letter to the Daily Iowan, student Everett C. Frost explained that his obstruction of a CIA recruiter grew from his commitment to "a university system whose goal is the creation of a free society." The CIA, "whose existence and practices are an obscene mockery of such a free society," was fundamentally incompatible with that goal. At the same time, he was "personally committed to the principle of non-violence," and therefore "chose to oppose [the CIA recruiter] by sitting-in," in the hope that his non-violent act "in some small measure represented all those peoples of the world whose lives have been hindered, manipulated or destroyed by the totalitarian practices of the CIA. ${ }^{36}$

The 'sit-in' method of nonviolent resistance formed the basis of student protest in these cases, but student radicals soon found new, much more unorthodox ways of protesting. For example, on November 1, 1967, students marched to the Old Capitol building and presented President Bowen with petitions that decreed the university's complicity in the Vietnamese War. These petitions contained 300 student and faculty signatures, all signed in blood. Twelve students were permitted into Bowen's office to deliver the signatures, while fifty other demonstrators crossed from the English-Philosophy Building to dump their own blood from paper cups onto the Old Capitol steps. They did so beneath a sign that read, "Let the bleeding end here." ${ }^{37}$ Similarly, SDS organized a burning of plastic dolls "to illustrate the burning of civilians by U.S.

35 "Harry and Sidney and Sammy" refers to three of America's black pop-culture icons of the time: Harry Belafonte, Sidney Poitier, and Sammy Davis Jr.; Phil Ochs, Love Me I'm a Liberal, CD (London: Elektra Records, 1966).

${ }^{36}$ Everett C. Frost, "Letter to Nic Goeres, Subversive Editor," The Daily Iowan, January 19, 1967, Student Protest Vertical File, University of Iowa Special Collections.

${ }^{37}$ Mike Finn and Roy Petty, "Demonstrators to Protest UI Complicity-In Blood," The Daily Iowan, November 2, 1967, Student Protest Vertical File, University of Iowa Special Collections. 
napalm in Vietnam, as a protest against Dow Chemical Company." 38 The Dow Chemical Company manufactured napalm, which was used by the U.S. armed forces to bomb North Vietnam. SDS was given tentative permission by the university to display the collage of dolls, but the act of burning was not officially sanctioned. The university administration called the doll burning "illegal" and "a breach of trust." 39

Still incredibly active on campus, SDS led the majority of 1967's student protests. However, the same tension that was left in the wake of the doll burning incident was still brewing between SDS and the administration at all the 'nonviolent' protests that occurred on campus. These tensions first spilled over at a protest on November 1,1967, where students and faculty members attempted to obstruct student interviews with Marine recruiters. Robert F. Sayre, an associate professor of English, wrote to the Daily Iowan explaining the radicals' reasoning. "The U.S. government is fighting an immoral, illegal, unjust war in Vietnam, and the Marines - much against the will of many of their officers and men - are deeply involved in it," he wrote. "Stopping the recruiters is not a matter of preventing them from talking, but preventing them from killing." 40 Around 200 students blocked the east entrance of the Iowa Memorial Union from 9 am to $12 \mathrm{pm}$, but they faced attacks from students and locals who were counter-demonstrating. This illustrates that, although very vocal, student radicals were a minority of the university population. Soon, local police, highway patrolmen, and sheriff's deputies from neighboring counties, equipped with riot helmets and clubs, moved in on the demonstrators. 108 students were arrested. ${ }^{41}$

On November 3, 1967, the Daily Iowan reported that President Bowen would be taking disciplinary action through regular university procedures against the 108 arrested students. The University did not usually take disciplinary action against students involved in civil liberties cases, but A.B. Hood, professor of education and chairman of the Committee of Student Conduct observed, "In this instance [Bowen] thought the students had broken

38 Roy Petty, "Plastic Dolls Burn on Campus," The Daily Iowan, December 5, 1967, Student Protest Vertical File, University of Iowa Special Collections.

${ }^{39}$ Ibid.

${ }^{40}$ Robert F. Sayre, "Letter to the Editor," The Daily Iowan, October 31, 1967, Student Protest Vertical File, University of Iowa Special Collections.

41 Templer and Hooven, "108 Arrested," The Daily Iowan, November 2, 1967, Student Protest Vertical File, University of Iowa Special Collections. 
a university rule by denying other students their right to enter the Union." 42 The students, who had maintained their nonviolent stance during the protest and after their arrests, felt this to be a betrayal by the administration. Dave Margoshes, who participated in the demonstration, told the Daily Iowan:

Liberal Reasoning has long held that the foundation upon which Civil Rights and antiwar demonstrations are based in the principle of free speech and that police interference in such protests constitutes an abridgment of protestors' rights. But the radical peace movement, in recent months, has become disenchanted with many of its old arguments. Clearly many members feel the time has come to stop merely protesting and begin to resist. ${ }^{43}$

This arrest of student radicals and the subsequent decision by the university administration to take action against those students was the first in a chain of catalysts that pitted student protestors directly against the university administration.

The new attitude of resistance toward the administration fueled a fire that exploded on December 5, 1967, when students, faculty, and local activists gathered to obstruct recruitment interviews conducted by representatives from the Dow Chemical Company. Before the protest, Middle Earth distributed a flyer instructing students on how the demonstration was to be conducted and what to do if they got arrested. Were the students simply coming prepared for the possibility of police backlash, or were they hoping that an escalation of their movement would push the police into a confrontation? "If we can't stop Dow, we'll have to stop the university," the flyer read. "We plan to be non-violent, and we plan to stay within the limits of the law. BUT WE DO NOT PLAN TO BE IGNORED." 44 The group, comprising roughly 200 protestors, took the demonstration from the Memorial Union, to the Library, to the English Philosophy Building, to the Pentacrest and the steps of the Old Capitol, where they defaced the building by writing "Revolution Now" in spray paint. ${ }^{45}$

\footnotetext{
${ }^{42}$ Mary Clark, "Arrestees to Face Dean-Disciplinary Action Promised," The Daily Iowan, November 3, 1967, Student Protest Vertical File, University of Iowa Special Collections.

43 Templer and Hooven, "108 Arrested."

44 "Stop Dow Now," Middle Earth (1968), Student Protest Vertical File, University of Iowa Special Collections.

45 James Flansburg, "Protestors Stopped from Reaching Recruiters by Police with Clubs and Mace," Des Moines Register, December 10, 1967, Student Protest Vertical File, University of Iowa Special Collections.
} 
In the Iowa Memorial Union, the avant-garde community spurred the protest on by using its musical influence. Here, we see a direct link between the ideology of student protest and the Iowa City music scene. Demonstrators and local musicians gathered in the IMU to sing "I Won't Fight Your War," accredited to Dennis Ankrum and SDS:

\section{On December 5}

The DOW man thought he'd try.

Came down with stacks of contracts,

Some consciousness to buy!

When he got to Iowa,

Had quite a job to do...

It took three hundred cops

To get that fucker through!

And I won't fight your war,

I'm on the other side.

I'm gonna choose

For what I live and die.

I'm here to place my body on the line.

I'm through with pouring water,

It's the fire next time.

Come gather round us, people,

And help us in our song.

We've got a movement going.

Why don't you come along?

We've got a lot of work to do.

Why don't you lend a hand?

If everybody does their share

We're gonna free our land.

And I won't fight your war,

I'm on the other side.

I'm gonna choose

For what I live and die.

I'm here to place my body on the line. 
I'm through with pouring water,

It's the fire next time. ${ }^{46}$

What is important to note about this song is not only its original purpose specific to this protest, but also the line "I'm through with pouring water / It's the fire next time." This line seems to promise violence in the future if the protestors' demands to "Stop Dow Now!" are not met. Similarly, a poem entitled "Powerless, With a Guitar," read by student Randy Miller on the steps of Old Capitol during the protest, spells out how music and student voices could be dangerous for the administration: "Our well-founded protests, which at any time / we may compose, fold, stamp, mount up. / Impotence, tried out on rubber facades / impotence puts records on: impotent songs / powerless, with a guitar / but outside, finely meshed / and calm, power has its way." 47 Miller's words were delivered at an anti-Dow rally on February 12, 1968. They speak to the perception of the powerlessness of music shared by skeptical people outside the movement. However, as Miller points out, when music melded with a tightly organized, calm movement of student activism, it could be powerful in a new way. The Middle Earth correspondent who reported on the rally remarked of the poem's recitation, "The few cops standing around were not amused—but everybody else was." ${ }^{48}$ Just like Bob Dylan's conscious soldiers against the "Masters of War," these students were not fooled, not afraid, and could not be contained.

The line between civil disobedience and violence was blurred at the Dow protest, as counter-demonstrators attacked radical protestors and police converged on the demonstrators with clubs and mace. These attacks show that the line of nonviolence was not blurred by the protestors, but rather by those reacting against student activism. The first instance of physical violence at the December $5^{\text {th }}$ demonstration sowed the seeds of a bitter rivalry between the police and student protestors. This rivalry would become a key motivator for student activists in the years to follow.

In their next issue, Middle Earth featured stories of students who had participated in the demonstration, including David Grant, who had been

\footnotetext{
${ }^{46}$ Dennis Ankrum and SDS, "I Won't Fight Your War," On a Confrontation in Iowa City, directed by Robert Coover (1968; Iowa City: The University of Iowa, accessed April 24, 2015), streaming video.

${ }^{47}$ Randy Miller, "Powerless, With a Guitar," Middle Earth 1, no. 11 (1967), Underground Publications, University of Iowa Special Collections. 48 Ibid.
} 
haunting the campus the previous week dressed as Death itself to make a statement against the war. Earlier in the week, Grant had been ejected from the Memorial Union for wearing a dark cloak and carrying a sign that read, "I am Dow's only recruit: Death." ${ }^{49}$ Grant was arrested during the protest for lighting a fuse under a cardboard box with signs reading, "Napalm Means DEATH!" Grant maintained, "I set this symbol of frustration about Dow's napalm between the police and the demonstrators. I did not see anything illegal about this, and to make sure there would be no misunderstanding of a possible bomb-threat, I said, 'This is symbolic,' as I placed the contraption on the ground." 50 The police, no doubt, saw the act of lighting a fire in the midst of a tense protest as a violent one, despite Grant's 'nonviolent' claims. One of Grant's classmates, Karen Harvey, was also arrested that day on charges of disorderly conduct. Regarding the arrest, she wrote in Middle Earth:

I planned to make a statement and then present a dead rat to the police who were lined up in front of the Civic Center. As I approached them, several yelled, 'Get her!' They charged from the right of me; I dropped the rat. They grabbed me from behind, without saying anything. Some others jumped me as I tried to pass my camera to safety. I was hit in the mouth with one of their clubs, but their clubs weren't very effective as they kept getting in each other's way. Four policemen carried me into the police station. I was not informed that I was under arrest for another hour, nor told of the charges. ${ }^{51}$

Harvey, Grant, and sixteen of their counterparts were arrested during the protest. Eight of the detainees had previously been arrested at the November $1^{\text {st }}$ protest. The Student Senate, though not condoning the demonstrators' actions, railed against the "excessive" bail, and voted to pay $\$ 1,500$ in funds to be used as bail for the four protestors who could not afford their own. However, the University, upon later legal advice, prevented these funds from being used for bail bonds. ${ }^{52}$

${ }^{49}$ David Grant, Middle Earth 1, no. 7 (1967), Underground Publications, University of Iowa Special Collections.

${ }^{50}$ Ibid.

${ }^{51}$ Karen Harvey, Middle Earth 1 no. 7 (1967), Underground Publications, University of Iowa Special Collections.

52 Des Moines Register, December 10, 1967, Student Protest Vertical File, University of Iowa Special Collections. 
Both sides of the December $5^{\text {th }}$ protest - the radical student population and the university administration - lobbied charges of breached trust against the other. President Bowen called the demonstration "irresponsible and unfortunate," telling the Daily Iowan, "This raises the question of the demonstrators' motives. Are they really trying to influence opinion, to change attitudes, to promote the pacifist cause?" ${ }^{33}$ City Manager Frank Smiley said in an interview, "What the university does in regard to those who were arrested will have something to do with it, but we're going to have law and order. We'll crack as many heads as need to be cracked." 54 This violent philosophy of the Iowa City police force further angered the protestors, who maintained that they had remained 'nonviolent.' Robert Coover, a visiting lecturer in the Department of English and the future director of a film about the protest entitled On a Confrontation in Iowa City, told Middle Earth:

That's the whole incredible thing about this demonstration. The demonstrators, as always, were nonviolent. They were unarmed, generally orderly, and most of the time seemed to be avoiding confrontations with the police. And yet the cops themselves seemed to be reacting toward them as if they were guerilla fighters or ghetto bomb throwers. The techniques they used in that Dow demonstration just weren't the right ones. In fact, just the contrary, it seemed to me that the high pitch of emotions that day was incited almost entirely by the police, not by demonstrators. Their indiscriminate use of mace and riot sticks, their taunting of students earlier in the day, their day-long pattern of sudden unexpected arrests - if their procedures could really be called arrests—all this just kept making things worse. ${ }^{55}$

Those who had participated in the demonstration maintained that university officials and the police had already planned to use violence against the demonstrators no matter the outcome of the day's events. Bert Marian, a student who participated in the protest, later said, "I had a feeling that whole day that our lives were governed by people who planned in advance exactly

\footnotetext{
53 The Daily Iowan, December 6, 1967, Student Protest Vertical File, University of Iowa Special Collections.

54 Ibid.

55 Robert Coover, "Eyewitness," Middle Earth 1, no. 7 (1967), Underground Publications, University of Iowa Special Collections.
} 
what we were going to do, how we were going to do it, and what the outcome was going to be_-and I don't mean us." 56

This distrust between the small faction of student radicals and authority figures within Iowa City would continue to fuel tensions, but the administration maintained that the protestors, being a small faction, posed an immature, naïve threat. "The number of students involved in the disturbances is less than one percent of the student body," Bowen said in an official statement. "This group is augmented by a number of young men and women who are not students here." 57 This assessment, while true, did not fairly capture the determination and intelligence of the student radicals. Gordon Young, a student but not a demonstrator, wrote to the Daily Iowan after the November 1st protest:

As was to be expected, the students were hepped up and talkative. Some wore sandals — others, beards. There were smug snickers and arched eyebrows among the cops and reporters: "What-else-couldyou-expect-from-these-hippies?" looks were exchanged. Some of us, who try to remain objective, however, couldn't help but be secretly proud of our fellow students. Regardless of their politics, these were dedicated, serious, and intense students who had succeeded brilliantly in doing what they set out to do: to impress upon the administration and public that they were fed up, furiously frustrated, in fact, with the war in Vietnam. ${ }^{58}$

This dedication, paired with the vilification of the university administration by student protestors, helped fuel the movement. While many liberal students hesitated to actively protest the war, many young, independent students could identify with the rebuttal of authority. The radical student faction, however, did not necessarily consider the Dow demonstration a victory for the student movement. "A successful protest must have political definition and must strive to raise the political consciousness of the people," wrote Randy Miller. "Our strategic objectives are very noble, but our tactical maneuvers must coincide with them." 59 Miller's issues with the protest arose from its descent into chaos-not all of which was the fault of the demonstrators. However,

\footnotetext{
${ }^{56}$ Coover, On a Confrontation in Iowa City.

57 "Bowen Explains Policy on Placement, Protest," The Daily Iowan, December 7, 1967, Student Protest Vertical File, University of Iowa Special Collections.

58 The Daily Iowan, November 4, 1967, Student Protest Vertical File, University of Iowa Special Collections.

${ }^{59}$ Randy Miller, "Mobilizing Activism," Middle Earth 1, no. 7 (1967), Underground Publications, University of Iowa Special Collections.
} 
individuals like Grant and Harvey, who acted independently of the organized tactics of the sit-in, jeopardized the protest's legitimacy. Disagreements like these on protest tactics would further lead to fissures within the movement in the next few years.

\section{By the Time We Got to Woodstock: The Shift in Iowa Student Protest, 1968-1969}

By the time we got to Woodstock

We were half a million strong,

And everywhere was a song and a celebration.

And I dreamed I saw the bomber jet planes

Riding shotgun in the sky,

Turning into butterflies

Above our nation.

\section{Woodstock; Crosby, Stills, Nash \& Young 1970}

Crosby, Stills, Nash, \& Young sang of the great hope for the success of the 'Woodstock Nation' and the utopian society that participants in the Woodstock Music Festival hoped to instill in 1969. This peaceful experiment, however, was a fairly isolated incident. In the years immediately before and after the festival, social movements both celebrated great victories and suffered paralyzing defeats. In this way, the years 1968 and 1969 were years of huge contradictions. The passage of the Civil Rights Act of 1968 occurred only after the assassination of the civil rights movement's greatest leader, Martin Luther King, Jr. The grassroots movements of the Democratic Party that brought Robert Kennedy to the forefront in the presidential election season failed when Kennedy was assassinated and the Democratic National Convention in Chicago erupted into a violent struggle between student protestors and the police. The Beatles' White Album, intended to promote peace and free expression, incited the crazed Charles Manson to commit heinous murders. Moreover, the Woodstock Nation of peace, love, and music, was crushed by the brutality and chaos of the Altamont Music Festival just four months after Woodstock.

This national atmosphere of victory and defeat, collective voice and chaos, shaped the student movement at the University of Iowa. Tragic events elicited contradictory reactions: either the renewal of the belief in peace in the face of 
violence, or the angry dedication to fight fire with fire. SDS, quickly radicalizing, faced both inside and outside opposition. The introduction of new players, like the New University Conference (1968), brought new issues to the forefront of student protest-namely concerns with the black civil rights struggle, women's liberation, and the destruction of Reserve Officers' Training Corps (ROTC) on campus. Simultaneously, the music scene split between peaceful folk protest and the introduction of drugs, blues, and anger toward the capitalist music industry. Nonetheless, the student protest movement at Iowa grew. This was made possible by peaceful protests that fostered unity both amongst different factions of student activists and between student radicals and university officials. This peaceful atmosphere was fragile, however, as an underlying tension continued to grow.

If Woodstock served to represent the peaceful ideals of the student protest nation, the Altamont Speedway Free Festival, held just four months later, crushed those ideals. As the Rolling Stones were playing their set, several white members of the Hell's Angels biker gang (which had been hired as security for the Stones) brutally stabbed a black audience member to death. Two other deaths, multiple thefts, numerous hospitalizations for drug overdoses, and several counts of vandalism also destroyed the event's free musical spirit. Altamont represented the violent edge of blues and rock music that was sharpening in 1969. This edge was present in Iowa City as well, as more and more blues acts came to prominence. One such act was the Mother Blues Band, formed by Patrick Hazell, an Iowa native, in 1968. Hazell reflects on the confrontational attitude of their music in an account of a confrontation with the police at one of their concerts in 1969:

I just started playing the harmonica right in the cop's face. The crowd started all gathering around, picking stuff up-bottles or whatever. They started just playing percussion, beating on stuff, gathering around these two cops. They looked at each other, they looked at this crowd. They got the hell out of there as soon as they could. Well, yeah. We probably were too loud. We probably were just being little assholes up there, but that's what happened. It was at a point that the cops were the adversaries. They had already done enough things that pissed people off. ${ }^{60}$

These examples of music fueling confrontation between authority figures and young artists reflected the tensions that were still present in Iowa City after the

${ }^{60}$ Hazell interview. 
arrests of protestors in 1967. These tensions would culminate in many more showdowns between police and protestors-showdowns that inspired further protest in blues and rock music.

Similarly, young audiences were becoming more and more fed up with the capitalist music industry that had produced their favorite 'anti-establishment' artists. This was reflected on an international scale at the Isle of Wight Festival in 1969, later nicknamed the "Hate-The-Performer-Festival." Audiences at the Isle of Wight heckled and jeered at performers like Joni Mitchell, who fans felt had betrayed countercultural ideals in order to make money. This reflection did not escape music enthusiasts in Iowa City. One angry student wrote to the Daily Iowan:

You sweetly believe that the Beatles, a multimillion-dollar manufacturing corporation, are at one with you, truly opposed to big business and the system and all that. They get you both ways, man. RCA sells military equipment, reports on its use in Vietnam through its subsidiary NBC, and then puts out records by the Jefferson Airplane, protesting it all. ${ }^{61}$

The concept of 'free music,' which had previously been established in Iowa City by the Center for New Music, did not include free records or free admission to rock shows. When Led Zeppelin played in the Iowa Memorial Union in 1969, one student refused to pay the two dollar admission and crashed the gate, yelling, "Free music for free people!" ${ }^{2}$ The admission price of the show (which was only two dollars) and the growing profits of musical icons contradicted the anti-capitalist ideology that many student radicals adhered to, and they felt betrayed by musicians who claimed to share the same ideals. The tensions that these contradictions created would lead to an overhaul of the music scene in Iowa City in the subsequent years of student protest.

By 1968, many of the organizations for social change fissured, and a small fraction of each became militant. SDS was the greatest example of this phenomenon. The events of 1968 brought many new radicals into the SDS fold. Steven Kelman breaks down the rise in enrollment thusly: "The new influx of people into SDS during 1968 was of a rather different type from those originally attracted... Only a few of them actually ever became active in SDS,

${ }^{61}$ "You'll Hear from Us," The Daily Iowan, February 2, 1969, Student Protest Vertical File, University of Iowa Special Collections.

${ }^{62}$ Hazell interview. 
but large numbers gathered around the fringes for the big events. Among these people the key word was 'frustration."' This frustration mostly stemmed from the years of thankless peace work that seemed to get the movement absolutely nowhere. "Frustration with not getting results from the system is by far the most frequent reason given by kids for joining SDS," Kelman writes. "The standard line goes something like, We wrote letters. We marched. We worked for McCarthy. But still the war went on."'63 The nation-wide events in 1968 and 1969 seemed to crush many student activists' belief that a peaceful, grassroots revolution could be won.

The national leadership of SDS, which had been slowly radicalizing for some time, saw the opportunity to implement their new-found slogan, rooted not only in an abstract socialist ideology, but also specifically in international revolutionary efforts: "Power to the People!" The Ohio State chapter of SDS published a pamphlet in 1969 that declared the "people's war," entitled "Let the Voice of the People be Heard":

The wealthy Americans had their revolution in 1776 but now, in 1969, the poor people of the world are having theirs. Guatemala, Santo Domingo, Cuba, China, Vietnam, the Ryuku Islands, Angola, the black colony in the United States - all these people are saying: "No, WE WILL NO LONGER BE RULED BY THE RICH.” All power to the people! Dig it—you don't make a million a year. All you do is work and die for the ones who do. The revolution has come. You are one of the people. Which side are you on? ALL POWER TO THE PEOPLE. LONG LIVE THE VICTORY OF THE PEOPLE'S WAR. ${ }^{64}$

It seemed that many members of SDS were, indeed, through with pouring water. It was the fire this time, and those who refused to join them would be in danger of its flame. This ideology culminated most infamously in the rise of the Weathermen, a militant faction of SDS that aimed for the eventual overthrow of the U.S. government. Their methods included a bombing campaign that targeted several state and national buildings across the U.S. The Weathermen took their name from the line "You don't need a weatherman to know which way the wind blows," from the Bob Dylan song "Subterranean Homesick Blues," which further showcases the role of music as a voice for

${ }^{63}$ Kelman, Push Comes to Shove, 121-122.

${ }^{64}$ Ohio State Students for a Democratic Society, "Let the voice of the People be Heard," in V andals in the Bomb Factory, ed. G. Louis Heath (Philadelphia: Scarecrow Press, 1976), 265. 
radicals. SDS was quick to distance themselves from the violent bombings carried out by the Weathermen, especially when they went underground to avoid arrest. There still remained, however, a militant faction of SDS which provoked not only riots against the police and the university administration, but also the destruction of several campus buildings. By 1969, SDS had shifted to the slogan "Build not, burn." 65 This was the language of the new, more militant student left.

Of course, not every student radical or member of SDS was supportive of this shift to a militant revolution. This was especially true at the University of Iowa, where SDS split on many issues, including the question of militancy vs. civil disobedience. Many student activists felt that the violent events of 1968 should not sway radicals to more violent action. To the contrary, they felt that these events proved that violence was the very antithesis of progress, and could only be combatted with education and peaceful action. One editorial in Middle Earth outlined a scathing warning to the militant members of SDS:

To expand in our situation is to build a base by education; by nonviolent action. We must create a conscience among the people who have slept so long. They are starting to wake up, and now we must provide intelligent, sensitive leadership, not hurl insults and press for violent disruption. If SDS determines to move on to militancy, it must face the very real fact that it does not have any power, that it has not gone very far at Iowa in terms of real sympathy and support. It could be smashed flat before its collective voice had a chance to even try persuasion. ${ }^{66}$

It is clear in these words that the original base of student protestors at the University of Iowa intended to maintain its efforts to combat ignorance and suppression at the local level. They felt that the events of 1968 and 1969 were proof of the corrupt nature of society, and, as the people began to "wake up," they could use the attention to focus on nonviolent action. The tension between these two competing ideologies—one based upon continuing to raise consciousness, and one based upon a complete overhaul of the system through a people's revolution - would inform student protest at the University of Iowa for the next three years, and ultimately sowed the seeds of the movement's destruction.

${ }^{65}$ Kelman, Push Comes to Shove, 105.

66 "SDS," Middle Earth 1, no. 7 (1967), Underground Publications, University of Iowa Special Collections. 
SDS was further conflicted by the rise of radical movements from other demographics of society. The most prominent of these were the Black Panther Party and the women's liberation movement. SDS attempted to cater to the African American and female populations of their own ranks by expanding their movement to include the struggles of these minorities. SDS encouraged radical women to join in the revolution for their own purposes- to end the systematic oppression of women. "We're SDS women fighters and we're part of the Revolutionary Army that's gonna take this country away from the few, and give it back to all the people including women," read one SDS declaration. ${ }^{67}$ SDS not only stood with its female members, but also with its African American ones. On April 14, 1969, SDS at Georgetown University circulated a newsletter entitled "Bob Dylan on White Skin Privilege," which included the lyrics to his song "Only a Pawn in Their Game," written about the assassination of civil rights leader Medgar Evers:

The deputy sheriffs, the soldiers, the governors get paid

And the marshals and cops get the same.

But the poor white man's used in the hands of them all like a tool.

He's taught in his school

From the start by the rule

That the laws are with him

To protect his white skin,

To keep up his hate.

So he never thinks straight

'Bout the shape that he's in.

But it ain't him to blame.

He's only a pawn in their game. ${ }^{68}$

By publishing these lyrics, SDS attempted to open up a dialogue between the largely white members of the student movement and their black counterparts. By calling poor whites "a pawn in their game" they showed how institutionalized racism victimized both black and white citizens, and attempted to encompass the civil rights struggle in their broader fight for change. Their

${ }^{67}$ University of Chicago SDS, "Women, Rise Up!" in V andals in the Bomb Factory, ed.

G. Louis Heath (Philadelphia: Scarecrow Press, 1976), 365.

${ }^{68}$ Georgetown University SDS, "View from the Outside," in Vandals in the Bomb Factory, ed. G. Louis Heath, (Philadelphia: Scarecrow Press, 1976), 321. 
use of Bob Dylan's lyrics further illustrates that the student movement relied on music as a tool to unify their followers and to amplify their message.

It was through the broadening of issues within the movement that the New University Conference found its local foothold. Howard J. Ehrlich, an associate professor of sociology and anthropology, was the leader of the NUC. He told the Daily Iowan, "The NUC believes in the rejection of the idea that the university preserves its integrity by passing on the commonplace opinion of the now dominant groups and forces of American life. We believe in the university that does not hesitate to incorporate radical thought into its curriculum." ${ }^{69}$ The NUC had a broad vision for the protest movement that included draft resistance instruction, elimination of the ROTC from the university, investigation into employment and academic disparities affecting women, and the expansion of scholarships and opportunities for black students. The New University Conference specifically proposed an investigation into the criteria used by the University for selecting recipients of the Martin Luther King, Jr. Scholarship, which had been created by President Bowen. After Dr. King's assassination in April, 1968, Bowen raised \$50,000 for the scholarship, but the NUC argued that the University had not kept its promise to recruit African American students who were economically disadvantaged. The NUC offered an outlet for radical faculty members and older students, and soon became a very important player in the student struggle on campus, especially for minority students.

White and black students at Iowa shared the anger and despair of people across the country who rioted after King's assassination. On the conflict, Middle Earth said, "What has been taking place in cities all over the country in the last few days is a response to years of frustration with white America's 'solutions' to ghetto problems." 70 In line with SDS's rhetoric toward white and black student protest struggles, Middle Earth's "white America" was limited to the elite members of white American society. The white student supporters of Martin Luther King, Jr. felt equally frustrated by the assassination of a peaceful leader against systematic racial oppression. Iowa City, however, was not a site of violent demonstrations. Rather, SDS sponsored university-wide participation in a national day of mourning and unified protest known as Black

69 "Radical Faculty to Form Group," The Daily Iowan, September 19, 1968, Student Protest Vertical File, University of Iowa Special Collections.

70 “Boycott!" Middle Earth 1, no. 15 (April 1968), Underground Publications, University of Iowa Special Collections. 
Tuesday. A flyer circulated by SDS said of the boycott, "Black Tuesday must be the day to move beyond pious words while America is burning down." 71 The flyer encouraged students to boycott classes in order to discuss more important issues of racism, poverty, and exploitation in America. The students demanded more classes that focused on African American culture and history, as well as more scholarships for black students proportionate to the number of black students on campus. President Bowen, while supportive of the peaceful demonstrations, ruled that classes would still be held during the boycott.

If Bowen's refusal to cancel classes further alienated him from the student movement, Dean of Academic Affairs Philip Hubbard's editorial in Middle Earth attempted to strengthen the administration's support for peaceful student protests. The fifteenth issue of Middle Earth's cover featured a glorified depiction of Dr. King above the words "Don't Mourn. Organize." Hubbard, the first African American faculty member at the University of Iowa, published his opinion in a piece entitled "And They Crucified Him." Hubbard wrote with a black perspective on King's death, lamenting, "It was almost as if I had known earlier of his death, and the announcement was simply late in arriving. In order to understand this feeling on my part, it may be necessary to have black skin, to live in this country, and to have been steeped since birth in the Christian ethic." 72 However, Hubbard was disturbed by the violence that had swept the country after King's death. He pleaded with the readers of Middle Earth:

Brotherly love was at the heart of the matter, of course, so that the doctrine of nonviolence followed naturally when it became necessary to take a stand against exploitation without violating basic Christian beliefs. This belief was held by Dr. King right up to the day of his death... If this principle is not emphasized by someone in the leadership of the Civil Rights movement, then I fear that we are in for an escalation of conflict which will turn this country into an armed camp. For the readers of Middle Earth, education should be a watchword. You represent a treasure house of talent in ideas and communication through all the arts. ${ }^{73}$

${ }^{71}$ University of Iowa SDS, “Students, Boycott Classes on Black Tuesday!” Student Protest Vertical File, University of Iowa Special Collections.

72 Phillip Hubbard, “And They Crucified Him,” Middle Earth 1, no. 15 (April 1968), Underground Publications, University of Iowa Special Collections.

${ }^{73}$ Ibid. 
It is clear from these words that Hubbard supported the students' right to free expression and protest as long as it centered on the principle of nonviolence. Unfortunately, this principle would not shape all of the protests at the University of Iowa in the years to follow but, in 1968 and 1969, the spirit of peace still permeated throughout many student demonstrations.

The participants of the Black Tuesday demonstration on campus were quick to draw parallels between the civil rights struggle and the anti-war movement. SDS's flyer announced:

We must come together as students to demand chance... Racial strife, the war in Vietnam, the Dominican Republic, and Guatemala, and even the recent economic crises have more than shown that we need immediate changes in our foreign and domestic policies. Any student on campus can remind us of the immediate changes we need here." 74

On October 15, 1969, SDS and the NUC came together to host the Vietnam Moratorium for Peace. The Daily Iowan reported, "The rally and march ended a day of nationwide discussion, demonstration, and boycotting of college classes and work-all aimed at persuading the Nixon administration to stop the war in Vietnam." 75 The University of Iowa's demonstration included poetry readings, draft counseling sessions, open mics, a symposium, a sunrise mass on the Pentacrest, and a candlelight vigil at the Old Capitol.

If the leaders of SDS were quickly radicalizing, and the nation-wide nature of student protest was becoming more confrontational, then why were the demonstrations on Black Tuesday and the Vietnam Moratorium for Peace so peaceful? One reason for this is undoubtedly the participation of the university administration in support of these demonstrations. President Bowen believed that the university setting should be "a place which is open to the truth and in which the truth is found through reason, discussion, and experiment, not through pressure, threats, and violence." 76 Thus, he supported the students' rights to free speech and open discussion during his presidency. In that same vein, there were no extra policemen or members of campus security on duty

\footnotetext{
74 University of Iowa SDS, "Students, Boycott Classes on Black Tuesday!"

75 "University Pauses for Moratorium," The Daily Iowan, October 16, 1969. Student Protest Vertical File, University of Iowa Special Collections.

${ }^{76}$ Bowen resigned in 1969, so his term coincided with Black Tuesday. He had left office before the Vietnam Moratorium for Peace. Persons, The University of Iowa in the Twentieth Century, 197.
} 
during these protests. The university's effort to give the students a legitimate platform for speech and peaceful demonstration no doubt contributed to an environment of free expression that did not leave the demonstrators feeling threatened. As such, support for student activism grew. The Moratorium was made up of over 6,000 protestors - roughly one-eighth of the population of Iowa City. ${ }^{77}$

This is not to say that student protestors favoring more extreme tactics did not exist at the University of Iowa. To the contrary, mounting tension was still present in the destructive faction of student protest culminating in what Stow Persons refers to as "individual acts of lawlessness." 78 Several individual fire incidents and acts of vandalism occurred in 1968 and 1969. These incidents were not representative of the collective student attitude, but of a small group of student militants eager to make themselves heard. Simultaneously, SDS and the NUC were building their case against the ROTC on campus. In 1968, protestors from the University of Iowa presented a petition to Governor Hughes demanding the immediate discontinuation of the ROTC on campus. The demand for the dismantling of ROTC would prove to be a driving force behind demonstrations in 1970 and 1971. It is also important to note that tensions between police and student protestors during the demonstrations of 1967 had not been forgotten, nor had they subsided. These tensions would soon explode, turning Iowa City into a battleground.

\section{Street Fighting Men: Iowa Student Protesters' Last Stand, 1970}

Hey! Said my name is called disturbance.

I'll shout and scream. I'll kill the king. I'll rail at all his servants.

Well, what can a poor boy do

Except to sing for a rock 'n' roll band?

Cause in sleepy London town,

There's no place for a street fighting man.

\section{Street Fighting Man, The Rolling Stones 1968}

The underlying tensions that pushed small numbers of students to extreme, often confrontational tactics in 1968 and 1969 finally spilled over for good in 1970. When President Nixon ordered the invasion of neutral Cambodia in

\footnotetext{
${ }^{77}$ Idem.

${ }^{78}$ Ibid., 195.
} 
April of 1970, student radicals across the nation exploded in protest. As a candidate who had campaigned on ending the conflict in Vietnam, Nixon's invasion of Cambodia convinced many activists across the nation that gradual, democratic change was not the answer. As such, the student movement split even further-the extremists had their platform for revolution. The New University Conference slammed liberal inconsistency and called for a complete overhaul of the system, stating, "Violence occurs when people fight back. And they are right to do so. Peace is no substitute for liberation; it can only come in its wake. We are convinced that in 1970 students should use their energies not to campaign for liberal peace candidates, but to build the movement which will force those liberals to end the war." 79 They concluded that this outcome would require "a mass-based, militant anti-war movement," and a growing demographic of the student movement agreed. They did not consider this militant movement violent, but rather counter-violent in opposition to the attacks by police.

The incident at Kent State University, Ohio, on May 4, 1970, pushed more students across the nation to more extreme tactics and a desire to confront authority. Just four days after Nixon announced the invasion of Cambodia, protestors at Kent State launched a demonstration against the war and the ROTC on its campus. When the protestors set fire to the ROTC building, the National Guard was dispatched to campus, where several guardsmen opened fire on the unarmed protestors, killing four students and wounding even more. The massacre was the subject of a song by Crosby, Stills, Nash, \& Young, entitled "Ohio":

Tin soldiers and Nixon's coming.

We're finally on our own.

This summer I hear the drumming,

Four dead in Ohio.

Gotta get down to it.

Soldiers are cutting us down.

Should have been done long ago.

What if you knew her

79 "NUC Raps on Politics \& the Streets," Iowa City Oppressed Citizen, September 4, 1970, Underground Publications, University of Iowa Special Collections. 
And found her dead on the ground?

How can you run when you know? 80

The lyrics not only blamed President Nixon and the military for the death of unarmed students - students who were not confronting or assaulting either the police or other students-but also fostered a sense of unity among all student protestors through the use of lines like "We're finally on our own." This cry for united revolution spread even to the University of Iowa, as student extremists began defending other violent acts across campuses, including the burning and bombings of several ROTC centers. One student wrote in Iowa City's new underground paper, the Oppressed Citizen, "But we are not lunatics and our actions are not wanton. We want to live and we want to be free, and if the military suppresses life and freedom then we need to suppress the military." 81 Many student activists at Iowa (and, indeed, across the country) felt that the time for peaceful action had long passed, and blamed overbearing authority for driving radicals to more desperate measures and, eventually, physical confrontation.

By 1970, student outrage against authority at the University of Iowa fell on new shoulders: those of the new University President Willard 'Sandy' Boyd. In the spring of 1969, President Bowen suddenly resigned. Though he never specifically cited the campus uprisings of the last four years as a reason for his resignation, the volatile environment surrounding his presidency no doubt took its toll on the sixty-year-old Bowen. The Board of Regents appointed Academic Vice-President Boyd as Bowen's successor, and he was sworn in on July 1, 1969.82 Unlike Bowen, Boyd was not afraid to voice his opposition to the American presence in Vietnam, and he sympathized with the plea of student demonstrators. However, he did not believe it necessary for these ideas to disrupt the lives of all students or the administrative workings of the university. This is, most likely, why he supported the Vietnam Moratorium in 1969, but refused to suspend classes for the occasion. Though he personally felt opposed to the war, he maintained that the university should remain a safe setting for all students to voice their own opinions. To frustrated activists in 1970, passive opposition was not enough. The administrative cooperation with

\footnotetext{
${ }^{80}$ Crosby, Stills, Nash, \& Young, Obio, CD (New York: Atlantic Records, 1970).

81 "No 'Twisted Mind' Behind Math Center Bombing," Iowa City Oppressed Citizen, October 12, 1970, Underground Publications, University of Iowa Special Collections.

82 Persons, The University of Iowa in the Twentieth Century, 198.
} 
student demonstrators that kept the peace in 1968 and 1969 failed to placate the militant wing of activists in the wake of the Cambodian Invasion and the Kent State shooting.

With a shift in student attitude came a shift in student voice. Between the discontinuation of Middle Earth in 1968 and the intensification of student militancy in 1970, a new underground paper was established at the University of Iowa. The Iowa City Oppressed Citizen, a play-on-words on the already established local paper the Iowa City Press Citizen, published radical student thought and attempted to align local student identity with that of oppressed people around the globe. To most onlookers, this was a stretch, as the majority of student radicals at Iowa were white, middle- to upper-class youths. The paper addressed this criticism in one of their issues, explaining:

People have often stated, "Oppressed Citizen, huh.... Shit! You people don't look oppressed to me!” Our spirits ARE free, but physically we must continue to live under the same archaic, oppressive and exploitive economic, social, and cultural system that "oppresses" not only each of us but everyone around the entire earth that is touched by its parasitic diseases. So people, until our dreams are realized and the lives of all exploited people are truly free to breathe and become a whole we will continue to be "oppressed citizens." Dare to Struggle! Dare to Live! ${ }^{83}$

Though the producers and readers of the Oppressed Citizen had very little in common with those fighting for independence in Vietnam or even many fighting oppression in their own country, they felt that they all shared a common purpose: to "destroy Pig America," referring to all institutions of authority, especially the military. They pushed this message not only through revolutionary thought, but also through music. One issue published the lyrics to Jimi Hendrix's "If 6 Was 9":

White collared conservative flashing down the street,

Pointing their plastic finger at me.

They're hoping soon my kind will drop and die,

But I'm gonna wave my freak flag high, high.

Wave on, wave on!

Fall mountains, just don't fall on me.

83 “About Our Name: Let's Make Things Perfectly Clear," Iowa City Oppressed Citizen, November 23, 1970, Underground Publications, University of Iowa Special Collections. 
Go ahead on Mr. Business man, you can't dress like me.

Sing on, Brother. Play on, drummer... ${ }^{84}$

The radical student voice published in the Oppressed Citizen relied heavily on music to unify its readers into revolutionary action.

In its fourth issue, the Oppressed Citizen outlined their revolution through the words of Timothy Leary. Leary, hailed as the father of the LSD drug movement, spoke at a concert in Iowa City in 1969. The Mother Blues Band opened the show, which was held in a barn on the outskirts of town, and Leary urged the drugged-out audience to resist the 'system' by any means necessary. Leary's presence at the concert, along with the widespread use of LSD at the event, demonstrated the influence of music and the counterculture on the youth of Iowa City. A year later, Leary was sentenced to ten years in prison for marijuana possession. In September, 1970, a month after his conviction, he was sprung from prison by members of the Weather Underground. On November 26, 1970, the Oppressed Citizen published his "Letter from an Escaped Prisoner of War." In it, Leary called all radicals to action. "I declare that World War III is now being waged by short-haired robots whose deliberate aim is to destroy the complex web of free wild life by the imposition of mechanical order," he wrote. "There is no choice left but to defend life by all and every means possible against the genocidal machine." 85 Leary outlined these revolutionary means in a few key words, namely "lovingly," "beautifully," "actively," and "physically." The Oppressed Citizen and Iowa student radicals organized in all of these ways in the protests of 1970.

Leary's first demand, that radicals resist lovingly, focused on loyalty to all factions of the radical movement. This included the Black Panther Party, the women's liberation movement, and the Gay Liberation Front. The student movement worked to ensure that all of these demographics were represented in the student demonstrations of 1970. For example, at SDS's Anti-ROTC Week in October of 1970, workshops were held not only on anti-war subjects, but also on the subjects of racism and sexism in Iowa City. ${ }^{86}$ Similarly, the

84 "All Power to the People," Iowa City Oppressed Citizen, October 5, 1970, Underground Publications, University of Iowa Special Collections.

85 Timothy Leary, "Letter from an Escaped Prisoner of War," Iowa City Oppressed Citizen, November 26, 1970, Underground Publications, University of Iowa Special Collections.

86"SDS Call for Anti-ROTC Week," Iowa City Oppressed Citizen, October 12, 1970 , Underground Publications, University of Iowa Special Collections. 
Oppressed Citizen's sixth issue featured a statement of the Gay Liberation Front at Iowa which encouraged action across all fronts. The article stated, "We recognize as a vanguard revolutionary action the Huey P. Newton statement on gay liberation. We recognize the Black Panther Party as being the vanguard of the People's revolution in Amerika. No revolution without us! An army of lovers cannot lose!" 87 In these ways, the student revolutionaries at the University of Iowa aimed to incorporate the struggles of all radical movements, and fulfilled Leary's call to "resist lovingly."

Leary also called for student radicals to "resist beautifully" through the creation of art and music. The Iowa City avant-garde scene had been resisting beautifully since its conception in 1965. In 1970, the musicians, artists, and film-makers all increased the production of their revolutionary art. Many of these artists wrote and sang to protest the draft, which had escalated with the implementation of the draft lottery in December 1969. The lottery randomly determined which men would be called into selective service in 1970 by birthdate. At this point, SDS and the radical student movement were no longer focused solely on draft resistance. Nevertheless, they encouraged young men to resist the draft in any way necessary. The NUC outlined several ways to resist the draft in the Oppressed Citizen, citing, "refusing induction, going to Canada, deserting after entering the army, sabotaging the army from within, ripping off the draft boards, filing for conscientious objection, not registering, not showing up for induction when ordered, and so on." 88 The new aim was to bog down the draft system by any means necessary. Activists believed that if active resistance could not shut down the draft, then perhaps becoming a dysfunctional $\operatorname{cog}$ in the draft machine might.

For several artists, these means were expressive. Diane Troyer, a film-maker in the undergraduate Writers' Workshop, protested through music and film. After her husband was killed in action in 1969, she felt her only way to honor his memory was through a film, which she entitled Nine in the Afternoon. "My film was a protest. It was a witch's scream," she said, "because my husband came home in a coffin." In the film, Troyer featured the sacrifice of a chicken.

87 The "Huey P. Newton statement" refers to a speech given by Black Panther Party leader Huey P. Newton in 1970 that recognized the Black Panther's solidarity with the Gay Liberation movement; "Out of the Closets and into the Streets! Statement of G.L.F.R.P.C.C." Iowa City Oppressed Citizen, November 23, 1970, Underground Publications, University of Iowa Special Collections.

88 “"The Draft is in Trouble," Iowa City Oppressed Citizen, October 12, 1970, Underground Publications, University of Iowa Special Collections. 
Of the act she said, "I figured if our government was spilling the blood of thousands it would be alright to sacrifice a chicken." 89 The film's soundtrack was composed of original music by the Mother Blues Band, not only illustrating the band's own opposition to the draft, but also the communal nature of the avant-garde scene. In May of 1970, the Associated Residence Halls even participated in the music community, inviting the popular psychedelic band Strawberry Alarm Clock to play at Lake MacBride for a "Love Sunday." The concert was in symbolic opposition to the draft, and the residence halls offered free admission and free busing to the concert site for all students. ${ }^{90}$

The musicians and artists in Iowa City also protested the overbearing nature of police authority. As previously mentioned, the Mother Blues Band had several run-ins with local officers. Similarly, the local band Linn County (previously named The Prophets) promoted this feeling with their hit song "Protect and Serve." Front-man Fred Walk said, "Our music was very much anti-police, anti-establishment, anti-government... A lot of the songs we wrote reflected that." 91 When Linn County moved to San Francisco's Haight Ashbury scene to record, "Protect and Serve" won them many fans who were also angered by police action against student radicals across the country. This reflected the influential nature of music not only nationally, but also locally in Iowa City. The writers of the Oppressed Citizen recognized music as an important tool of influence. Their advice columnist "Sweet Abbie" wrote in the very first issue, 'Music can tell us a lot if we listen to it. Shit, there ain't nothin' Dylan hasn't sung about. Our heads can really open up an' out through music. Music should be our philosophy — our human experience in getting it all back to the garden." 92 Her words "getting it all back to the garden" were a reference to the Crosby, Stills, Nash, and Young song "Woodstock." This further showcases the influence of music in the student revolution and the hope that, someday, the Woodstock Nation would be a national reality.

These musical expressions not only represented Leary's idea of beautiful resistance, but also promoted his call to "resist actively." This was most literally fulfilled in student demonstrations against the ROTC on campus. The vilification of the ROTC began almost two years earlier, but really hit its stride

89 Troyer interview.

90 "Events Planned at UI 'Love Sunday," The Daily Iowan, May 11, 1970, Student Protest Vertical File, University of Iowa Special Collections.

${ }^{91}$ Fred Walk, interview by Taylor Finch, August 31, 2015, Iowa City, IA.

92 "Sweet Abbie," Iowa City Oppressed Citizen, September 4, 1970, Underground Publications, University of Iowa Special Collections. 
at Iowa in 1970. Student radicals felt that the mere presence of the ROTC on campus made the university complicit in the violent war effort and, therefore, in the deaths not only of Americans in Vietnam, but also of thousands of innocent Vietnamese citizens. Iowa native Patricia Mullen wrote a letter to the Daily Iowan outlining this sentiment, saying, "How can you, in clear conscience, think that little boys parading around in groups with deadly weapons is a good and patriotic thing? Since my brother was killed in Vietnam in February in the name of 'freedom' I have no other desire than to see the forces of death and destruction - the U.S. military — wiped off the face of the earth." 93 On April 18, 1970, several protestors carried the heads of butchered hogs to the Pershing Rifle Regimental Drill Meet on campus. They also disrupted the ROTC events on Governor's Day (May 5), causing President Boyd to cancel the day's events. SDS considered this cancellation a massive victory, and used the momentum it gained them to plan more protests on May 8.

All of the events of that spring converged on the University of Iowa campus in May of 1970. The protests of May 8 were not only in opposition to the ROTC on campus, but also in reaction to the Kent State killings and the recently instituted draft lottery. The protest began peacefully, with about 300 to 400 protestors filing onto the Pentacrest. At its peak, the protest grew to include about 1,500 students and local activists. Unfortunately, demonstrators from the militant faction of student activists broke into the Old Capitol and adjacent Jessup Hall, breaking a few windows and smashing some furniture. President Boyd, who was not on campus at the time, ordered the Pentacrest to be cleared by police and campus security. One reporter for the Iowa City Press Citizen wrote of the decision, "Reports of incursions and a false fire report are believed to have been a major factor in Boyd's decision to ask officers to clear the Pentacrest." 94 As the police converged on the demonstrators and tensions mounted, the crowd began singing John Lennon's "Give Peace a Chance." Unfortunately, the officers did not heed this request, and over 200 students were arrested.

93 Patricia and Michael's mother, Peg Mullen, became a recognized national activist against the war and the draft. Her story was published in the book Friendly Fire by journalist C.D.B. Bryan. The book was later turned into a TV movie starring Carol Burnett. Peg also wrote her own memoir about her son's death, entitled Unfriendly Fire; Patricia Mullen, "Letter to the Editor," The Daily Iowan, April 18, 1970, Student Protest Vertical File. University of Iowa Special Collections. 94 "Officials Show Strain from Long Week," Iowa City Press Citizen, May 8, 1970, Student Protest Vertical File, University of Iowa Special Collections. 
The tensions between Iowa City police and student activists that began brewing in 1967 and intensified with the events of 1970 informed President Boyd's hasty decision to clear the Pentacrest on May 8. These tensions also led President Boyd to institute an emergency policy that banned intentional disruption of university activities, prohibited unauthorized entry or occupation of any university building, and forbade vandalism or harassment of any person on campus, upon penalty of suspension. After putting this emergency policy in place, Boyd felt confident that "the present level of tension on the campus has subsided and there are no further threats of violence to persons or property." 95 Unfortunately, this confidence was misplaced.

The extreme disciplinary measures that President Boyd felt would restore order in 1970 instead pushed the campus to the brink of chaos. Student radicals, fueled by tensions with university officials and police forces since the Kent State killings earlier that week, felt betrayed by the President's decision to arrest peaceful demonstrators. This was the final straw for civil disobedience on campus. Thus, demonstrators moved on to Leary's final plea, "resist physically." On May 9, 1970, the Old Armory Temporary, which held the rhetoric department and sat near the main library, burned down. Firemen at the scene attributed the disaster to arson. ${ }^{96}$ Simultaneously, 300 National Guard troops waited outside the city limits. The troops had been ordered there by Iowa Governor Robert D. Ray, and were on standby in case the rallies inside the city became more violent. ${ }^{97}$

Inside the city, a demonstration began at 9:00 PM. "The crowd, consisting of a mixed bag of activists, faculty, moderate students, and townspeople, varied from perhaps 300 early in the evening to more than 1,000 at its peak around 11:00PM," the Daily Iowan reported. ${ }^{98}$ They marched through the downtown streets to the Iowa City Civic Center to protest not only the arrests of their fellow radicals the day before, but also the arrests of seven black students earlier that week. The protestors also maintained their commitment to the abolition of the ROTC on campus. At 12:30 AM, President Boyd arrived on the Pentacrest to make a statement to these protestors. "The cause of peace will

95 "Boyd Suspension Statement," The Daily Iowan, May 8, 1970, Student Protest Vertical File, University of Iowa Special Collections.

${ }^{96}$ John M. Jeffries, "Guard Called; Building Burns," Iowa City Press Citizen, May 9, 1970, Student Protest Vertical File, University of Iowa Special Collections.

${ }^{97}$ Ibid.

${ }^{98}$ Fred E. Karnes, "Boyd Again Urges Calm and Reason," The Daily Iowan, May 10, 1970, Student Protest Vertical File, University of Iowa Special Collections. 
not be served by destroying this university," he urged. "I feel strongly that we can handle our problems internally. I urge you to move forward with me to complete this semester." 99 Boyd's statement convinced the student demonstrators to disperse peacefully, but the call for peace-a peace that student radicals felt Boyd and the administration had violated the previous night — came too late.

These tense demonstrations and the contemporaneous arson of the Old Armory Temporary led students to call for a university-wide strike. The radical student faction demanded in their strike negotiations that U.S. forces be immediately withdrawn from Indochina, all racist attacks on black people (especially members of the Black Panther Party) be halted, amnesty be given to all student protestors, all faculty affected by the student strike be paid in full, and, of course, that the ROTC be abolished from campus immediately. ${ }^{100}$ Some of these demands were obviously out of the administration's control, but the demonstrators were using the strike as a platform to push their message throughout the state and the nation. Student radicals, however, were not alone in their demand for the immediate campus shut-down. The campus strike was supported, at least in part, by moderate and even conservative students who feared the violent nature of the campus uprisings and confrontations with the police. As such, President Boyd gave the students the option to leave campus and end the school year early on May 11. In an official statement Boyd said:

In light of recent events and the tense emotional situation on campus, a number of students, fearing for their safety, have expressed the wish to return home. Their concern on this score has been heightened by the circulation of an incredible number of rumors throughout the University community, and it does not seem likely that their fears will diminish quickly. ${ }^{101}$

Students were given the options to complete their work at a later date, accept a pass or withdraw grade, or accept a grade based on the work they had completed through May 3. In the end, almost 12,000 students took the earlyout option. ${ }^{102}$ The event left the campus peaceful for the summer, but attitudes

99 Ibid.

100 "Students Call for Strike," The Daily Iowan, May 11, 1970, Student Protest Vertical File, University of Iowa Special Collections.

101 "Option to Leave Given Students," The Daily Iowan, May 11, 1970, Student Protest Vertical File, University of Iowa Special Collections.

102 "May 1970 Protests," Iowa City Press Citizen, May 8, 1999, Student Protest Vertical

File, University of Iowa Special Collections. 
about the accomplishments of May 1970 divided the student protest movement.

When the school year started up again in September 1970, the Oppressed Citizen printed a reflection on the events of the preceding spring:

It's been an interesting season for everyone; it'll probably be remembered as the summer Iowa City's hip community, long anticipated and eagerly awaited, took everybody by surprise simply by surviving. As it happened, however, the community belonged only to those people who were of it. They chose their issues and fought their battles, sometimes wisely, sometimes awkwardly, but through it all always learning. The schools are about to reopen, but that's not where the learning will be happening this winter. A lot of freeks [sic] will be doing a lot of reading and a lot of rapping and a lot of thinking... getting themselves together. It's been a good summer; a lot is clearer now. Last year we were almost willing to accept the media's image of ourselves as eccentric but harmless, flower-power peace creeps; we were so much older then... ${ }^{103}$

The last line of this statement is a clear reference to the Bob Dylan song "My Back Pages," in which he claims, "I was so much older then. I'm younger than that now." These words summed up the attitude of Iowa student radicals in the wake of May 1970. Rather than feeling deterred by the spring's events, they were encouraged. They were not willing to fade out as "harmless, flower-power peace creeps." Instead, they resolved to dedicate themselves once again to the cause of "physical resistance" on campus.

However, this sentiment did not speak to all student demonstrators at Iowa in the wake of the campus shut-down. One student from Iowa City High referenced a different song, "Eve of Destruction," to express his attitude toward the campus uprisings:

They don't have to attack us to defeat us. We can defeat ourselves unassisted, and they are willing to stand by and watch. We may very well be on the "Eve of Destruction" through our own doing. Let's all work together to take the question mark out of American, but let's do it the unquestionably American way. Do it through the processes that have survived nearly two hundred years and have

103 “High!" Oppressed Citizen, September 4, 1970, Underground Publications, University of Iowa Special Collections. 
brought us to the level of freedom and intelligence we experience today. ${ }^{104}$

This plea for order and the democratic process illustrates the division of student protest that occurred in early 1970. By the 1970-1971 school year, all of Timothy Leary's proposed methods of resistance-lovingly, beautifully, actively, and physically_ gained followers who began to work against one another. The militant faction's tendency to use vandalism, confrontation, and other extreme measures polarized the student protest movement. It was this polarization that would indeed spell the destruction of Iowa student protest by 1971.

\section{The End: The Decay of Student Protest, 1971}

Of our elaborate plans, the end.

Of everything that stands, the end.

No safety or surprise, the end.

I'll never look into your eyes...again.

Lost in a Roman wilderness of pain,

And all the children are insane,

All the children are insane.

\section{The End, The Doors 1966}

The campus arrests and arson of the Old Armory Temporary of 1970 proved meek in comparison to the violent events that shook the University of Iowa campus in 1971. The spirit of disillusion was all over campus. Student radicals felt frustrated that their efforts of the past six years seemed to garner no results. Meanwhile, student liberals and moderate protestors felt polarized by the shift to militant tactics that many of their counterparts had adopted. Some activists continued to organize peaceful demonstrations, but were foiled again and again by extremists who had once before dedicated themselves to those same efforts.

Eventually the majority of student activists dropped out in favor of a quiet sub-society. These activists were not only affected by violent confrontation, but also by the steady rise in drug use. Hard drugs caused the loss of several

104 Mike Finley, "From the Right," in Iowa "70: Riot, Rhetoric, Responsibility? ed. James H. Potter (1970), Student Protest Vertical File, University of Iowa Special Collections. 
music idols by 1972, and the student movement blamed itself. When the music died, so too did the hope of the Woodstock Nation. By December 1971, the student protest movement at the University of Iowa failed to mobilize even a handful of activists. The fire of revolution burned brightly for only a few months before smoldering away to ash.

In 1971 it became increasingly obvious to the moderate side of student protestors at the University of Iowa that they could not, in fact, speak for or relate to the struggles of many minority groups. In their seventh issue, the Oppressed Citizen published a letter to this effect:

We all know that only a middle-class white American can speak with such assurance about the new future, and "real" liberation, and about the futility of politics, and of violence, and all of that is the luxury that men afford themselves when everyone has it — or when they have forgotten those who don't. If we do not do it their waywith guns and irrevocable acts of violence against the state, then we have to do it some other way; we have to speak with our whole political lives a truth as transformative and as deep as theirs. We believe perhaps in what we do, but we do it still too safely, too comfortable. We have not yet — not most of us_-found a way to live or to speak in relation to oppression and repression that is as threatening to the state or as convincing and as appropriate to the time as the Panthers in their way. ${ }^{105}$

Some student activists took this to mean that they could not, in fact, effect change on a global or even a national scale. Still, others took this as a cue to throw off the relative safety of peaceful opposition and take up the flag of revolution.

Simultaneously, student demonstrators began to notice something strange about a few radical characters on campus. "I think there was something that didn't smell right," Patrick Hazell remembers. "People that I know have even so much as said that some of the big protest leaders in Iowa City... there was something not quite right about them. They didn't fit the hippie type. There was a lot of manipulation of the youth then... a lot of manipulation." 106 These leaders were thought to be government plants. The suspicion of student demonstrators was not misplaced. In 1956 (after years of secret spying) the

105 “New Schools Exchange," Iowa City Oppressed Citizen, November 20, 1970, Underground Publications, University of Iowa Special Collections. 106 Hazell interview. 
FBI, led by J. Edgar Hoover, officially enacted COINTELPRO, or 'Counter Intelligence Program.' Originally created to seek out and destroy black extremist groups, this program spied on organizations and individuals, and often placed FBI plants in their midst to spy or incite violence from the inside. In his article "How We Found out About COINTELPRO," Martin Oppenheimer points out that, "the FBI monitored and maintained files on 'members of unions, pacifist groups, anarchists, racial justice groups, and Bureau critics (who) were regarded by Hoover as subversives.' Tactics included persuading local police to arrest leaders 'on every possible charge."' 107 The tactic of arresting demonstrators on any and all possible charges was certainly used at the University of Iowa. The use of FBI plants was harder to prove, but the student movement had its suspicions.

Diane Troyer recalls throwing men thought to be informants out of a gathering at her home. "They were acting really disrespectful... weird to the women. That's how I knew. The rest of the people in that house were very sophisticated students and artists and professors, people who really understood what the movement was about." 108 Artists and musicians had special reason to be suspicious of Hoover and the FBI, whose infamous distrust of intellectuals had led to extensive spying upon those in the art community. ${ }^{109}$ Although no knowledge of a specific operation was present, and though the existence of FBI plants and spies could not be proven, the art community heard whispers. To spread awareness at Iowa, the Oppressed Citizen began publishing a column called "Narcs in the News" to inform students on the appearance and whereabouts of known informants. ${ }^{110}$ These names were often based upon speculation, but in May 1971, several police officers were discovered dressed in wigs and 'hip' clothing during a protest against police brutality. ${ }^{111}$ The presence of these plants and informants left many radicals doubting whether or not the cornerstone of the militant revolution even came from their peers within the student movement. This distrust corrupted the unified attitude and identity of student protestors.

${ }^{107}$ Martin Oppenheimer, "How We Found out About COINTELPRO," Monthly

Review: An Independent Socialist Magazine 66, no. 4 (September 2014): 54-60.

108 Troyer interview.

109 Oppenheimer, "How We Found out About COINTELPRO," 56.

110 "Narcs in the News," Iowa City Oppressed Citizen, November 20, 1970,

Underground Publications, University of Iowa Special Collections.

111 "More Arrests as War Foes Take Streets," The Daily Iowan, May 5, 1971, Student

Protest Vertical File, University of Iowa Special Collections. 
It turned out, however, that the student protest movement at the University of Iowa did not need the aid of government plants to disrupt its sense of unity. The chasm between militant protestors and student demonstrators that had opened in 1968 widened even further in early 1971. Both factions were still focused on the total withdrawal of U.S. forces from Southeast Asia (which by this point included Vietnam, Cambodia, and Laos) and an end to the ROTC, but they chose vastly different methods to implement their demands. Some student demonstrators hosted a "Teach-In Against the War" in February 1971, remaining committed to civil disobedience. According to Student Body President Bo Beller, the teach-in was intended to foster intellectual and peaceful change:

I urge everyone in the community to return to their classes with the provision that all classes be devoted to the discussion of the situation we find ourselves in, to confront our teachers and ourselves in order to discover the real source of our collective power and our collective outrage that we may direct ourselves to an effective means of stopping this machinery of war. Stopping the invasion of Laos means, among other things, stopping the invasion of our "humanity" by the repressive elements of this university and by our own apathetic complicity with these elements. Invade your classrooms. Strike there. ${ }^{112}$

The students running the teach-in attempted to draft a list of demands for the Board of Regents at the end of the day's events. The Daily Iowan reported, "The confusion between the programs and the demands caused some argument among the various group representatives at one point during the mass meeting. As a result, an attempt to vote support for the numerous demands had to be abandoned." 113 The very fact that the participants of the teach-in could not agree on their collective demands illustrated the gravity of the student split. The liberal leaders of the teach-in were forced to draft demands without a consensus.

Although the teach-in boasted a large turnout, student extremists were through advocating for intellectual change or civil disobedience. One spectator at the teach-in told the Daily Iowan, "I came because I'm ready for a deadline.

112 Lynne Joslin, "Students to Face Regents-Teach-in Draws 1,500 participants," The Daily Iowan, February 11, 1971, Student Protest Vertical File, University of Iowa Special Collections.

113 Ibid. 
I'm through demonstrating and I'm ready for violent action." 114 This extremist's words reflected a larger sentiment that had grown in the student protest movement over the last few years. The Oppressed Citizen printed an opinion in their penultimate issue to this effect:

Certainly it is a shame that people must take to the streets in an effort to end this damned war. But it is far more shameful that some 40,000 plus Americans are dead and countless more maimed, and that uncounted thousands of Asians are dead because of our aggression. Certainly we would far rather sit and intellectually rap against the war, but for years now we have talked, signed petitions, telegraphed, written letters, and in other quite passive ways worked against the war. And the dead pile up. ${ }^{115}$

The Oppressed Citizen simultaneously continued to endorse militant actions on campus. The writers hosted a "Would-be Revolutionaries Bombing Statement Contest" that provided a template for radicals to write their own bombing statements. "This is a contest!! Best bombing statement wins a free subscription to the Iowa City Oppressed Citizen and all the tinsel and glitter that goes with winning a big time contest," the paper advertised. "Entries will become the property of the people. With luck, they will also find their way into the police files." 116 The newspaper never advocated for violence against other students or civilians, but rather against specific building targets or "pigs." This endorsement not only encouraged solidarity between University of Iowa extremists and militant radicals across the nation, but also set a precedent for militant action in Iowa City.

Later, David Grant, a student activist in the 1967 protests, remembered, "When I returned to Iowa City in 1971, it was a new ballgame here-it was a mob. It was trashing, not shouting. It was bricks, not words." ${ }^{117}$ These bricks were hurled as early as February 1971. On the $12^{\text {th }}$, an SDS sponsored, antiROTC raid turned volatile when a procession of fifty protestors began smashing windows and furniture in the ROTC headquarters and the

114 Ibid.

115 “The Mad Dog Collective" Iowa City Oppressed Citizen, February, 1971,

Underground Publications, University of Iowa Special Collections.

116 "Would-be Revolutionaries Bombing Statement Contest," Iowa City Oppressed

Citizen, November 9, 1970, Underground Publications, University of Iowa Special

Collections.

117 "Academic Freedom in Heyday of Radicalism," The Des Moines Register, November 11, 1994, Student Protest Vertical File, University of Iowa Special Collections. 
Quadrangle dormitory. One student was arrested for burning the American flag, and others lit off firecrackers that broke holes in the glass doors of the dormitory. ${ }^{118}$ Three months later, anti-ROTC demonstrations turned even more confrontational when twenty-six were arrested in a window-breaking spree. Several students who had intended to organize a peaceful protest quickly jumped between the vandals and the glass windows of downtown buildings. The militant radicals began jeering at the student monitors, calling them "stooges, dupes, and little pigs." 119 This confrontation between extremists and radicals illustrated the very real resentment between the two factions of student protest. The powerful image of student activists placing their bodies between extremists and the property the latter were attempting to vandalize served as a reminder that not all students at Iowa had abandoned the mantra of peaceful civil disobedience completely. However, the actions of a few extremists poisoned the image of all student protestors, who were often looped together by onlookers despite their different methodologies.

The sudden outbreak of violence on campus shocked university administrators. President Boyd told the Press Citizen, "Last night's unlawful activities cannot be related in any way to the cause of peace." 120 The president failed to realize that many militant demonstrators no longer crusaded for peace, but rather confrontation with "Pig America." By this point, the extremists" motivations boiled down to flat-out rebellion against local authority. They saw this as a reaction to the violence of "Pig America" rather than a demonstration of political action. To illustrate this point, anonymous militants placed a bomb in the side entrance of the Iowa City Civic Center in the early morning hours of May 7, 1971. The bomb was placed and detonated after everyone had left the building for the night, and no one was hurt. Nonetheless, the bombing shook the University of Iowa administration and student body, as well as the citizens of Iowa City. "If a community were only bricks and mortar, you could destroy it this way," Mayor Loren Hickerson said, "[b]ut this kind of senselessness isn't going to weaken this city-university community. If anything,

\footnotetext{
${ }^{118}$ Lynne Joslin, "Protestors Raid ROTC; One Arrest," The Daily Iowan, February 12, 1971, Student Protest Vertical File, University of Iowa Special Collections.

119 Thomas C. Walsh, "Anti-War Rally Erupts into Free-for-All Here," Iowa City Press Citizen, May 6, 1971, Student Protest Vertical File, University of Iowa Special Collections.

120 Ibid.
} 
it will tend to strengthen it." 121 Unfortunately for the militant faction of student protest, this statement rang true, and the community united to silence student protestors for good.

The Civic Center bombing, followed by violent events in the next several days, elicited an immediate crackdown on student protest from both the university administration and city officials. On May 10, when a crowd of 300 rioted outside the male dormitories, Governor Robert Ray called in help from outside the city. City, state, and university officials supported Ray's decision to dispatch 200 additional Highway Patrolmen to Iowa City. ${ }^{122}$ This instigated student extremists to further violence. For three consecutive nights, patrolmen and students clashed downtown and outside the dormitories. The protestors were spurred on by Highway Patrol Captain Lyle Dickinson's decision to tear gas the demonstrators on May 11 and 12. Several of the canisters detonated outside broken windows, gassing students inside their rooms and forcing them out onto the streets. "When you get gassed out of your bed, you are ready to go out and rock a cop. It's really very simple to understand. They felt people were coming up here to attack them, and they were defending themselves," asserted Hillcrest Residence Hall Association President James Pendleton. ${ }^{123}$ Many student militants felt that the actions of police and patrolmen further justified their call for revolution. However, by the third night of confrontation, student bystanders had all but evacuated the dorms.

These violent confrontations were easily distinguished from the anti-war demonstrations of the previous year. "I've been with the university and their problems since 1967. I don't think you could in any way, shape, or form compare last year with this year," Dickenson stated. ${ }^{124}$ President Boyd urged the students to resist calls for aggression and agitation from fellow students. He told the Des Moines Register.

This week's events began as legitimate, peaceful, antiwar protests. As soon as the demonstrations became destructive and disruptive all of the legitimate antiwar groups pulled out. There hasn't been the

121 "Bomb Blast Damages Iowa City Civic Center," The Daily Iowan, May 7, 1971, Student Protest Vertical File, University of Iowa Special Collections.

122 Mark F. Rohner, "New Disorders Here; Damage at Dorms," Iowa City Press Citizen, May 11, 1971, Student Protest Vertical File, University of Iowa Special Collections. 123 “'Why?’ Most Asked, Least Answered,” Iowa City Press Citizen, May 12, 1971,

Student Protest Vertical File, University of Iowa Special Collections. 124 "Students, 125 Patrolmen Clash in UI Dorm Area," Iowa City Press Citizen, May 12, 1971, Student Protest Vertical File, University of Iowa Special Collections. 
massive response from the student body this year that there was a year ago. On the whole, I'm very proud of our student body; most of them have stayed completely out of this. ${ }^{125}$

Indeed, even SDS was quick to distance itself from the violent action. The vast majority of students, including liberal activists, wanted nothing to do with the riots. Many rightly observed that these were not anti-war or anti-ROTC protests, but rather riots specifically intended for clashing with the police and authority figures.

This alienation further reflected a national backlash against protests. A nation-wide survey conducted in 1970 by the Carnegie Higher Education Commission found that most students and professors felt that students who disrupted college operations should be suspended or expelled. ${ }^{126}$ The University of Iowa administration took this to heart and enacted a temporary injunction against all persons found taking part in disturbances on campus. This injunction, combined with the consistent use of police force and the resentment of much of the student body led to the eventual defeat of student militancy. By May 15, 1971, the extra patrolmen left their temporary quarters at the Iowa City Ramada Inn. ${ }^{127}$ The campus once again fell silent, this time for good.

The remaining student activists returned to peaceful protest measures for the rest of 1971. These measures included the 'drafting' of local officials into the peace movement and a temporary cemetery on the Pentacrest in June 1971 in memoriam of all war dead. ${ }^{128}$ However, the backlash against student extremism took its toll on all forms of organized protest. The first demonstration of the 1971-1972 school year, aimed at prison reform, failed to draw more than a handful of supporters. ${ }^{129}$ Many radical students dropped enrollment at the university altogether, and the NUC lost all but a few of its

125 Ibid.

126 "Punishing Campus Unrest," Des Moines Register, January 25, 1971, Student Protest Vertical File, University of Iowa Special Collections.

${ }^{127}$ Mark F. Rohner, "Everything's Peaceful Here, Highway Patrolmen Leaving," Iowa City Press Citizen, May 15, 1971, Student Protest Vertical File, University of Iowa Special Collections.

128 "Boyd 'Drafted,"' The Daily Iowan, June 8, 1971, Student Protest Vertical File, University of Iowa Special Collections.

129 This protest was a reaction to the infamous Attica Prison Riot of 1971; "First Protest Fails to Draw Crowd," Des Moines Register, September 16, 1971, Student Protest Vertical File, University of Iowa Special Collections. 
members by late 1971. ${ }^{130}$ The widespread conservative backlash put an end to student militancy, while the de-escalation of the war beginning in 1972 took away the legitimacy of many student activists' efforts. Soon, student protest at the University of Iowa faded into the recesses of history.

The music that had both driven and reflected student protest met its collective end as well. This was not only because of the conservative backlash against militant protestors, but also due to the loss of collective identity among musicians and audiences. Since the mid-Sixties, musical experimentation and expansion had been tied to drug use. These drugs, often called 'life drugs' by their users, encompassed mostly marijuana and LSD_hallucinogens that expanded the mind. This was promoted at the University of Iowa through experimentation with psychedelic music by bands such as the Mother Blues Band and Jefferson Airplane, who played on campus in 1970. Drugs were widespread at many of these concerts, especially at Timothy Leary's appearance in 1970. Diane Troyer remembers the effect the drugs had on concertgoers: "My mother said, 'That was the nicest group of people I've ever seen!' Well, they were all on acid..."131 The Oppressed Citizen published several reviews of psychedelic artists such as Don Ellis and the Grateful Dead. These reviews often ran alongside advertisements for the local radio show "Visions: Music for Your Mind," that depicted small characters surrounded by a haze of marijuana smoke. ${ }^{132}$

As the student and music movements became more hopeless and more violent, however, musicians and audiences turned to harder drugs. These included cocaine and heroin. The excessive use of these drugs contributed to the deaths of several notable musicians of the movement, including Janis Joplin, Jim Morrison, and Jimi Hendrix. The Oppressed Citizen lamented the loss of Jimi Hendrix in a eulogy featured in their fourth issue. The eulogy blamed Hendrix's death on the "hollowness of the youth culture" which had allowed the spread of hard drugs, disillusion, and violence:

More and more we find people of all races and social classes trying to escape through smack. Loneliness, alienation, and despair make smack attractive to increasing numbers of young people. Even the famous. Even the rich. Even Jimi Hendrix. This wouldn't be the case

130 Persons, The University of Iowa in the Twentieth Century, 203.

131 Troyer interview.

132 "Bee-bop and Razz-ma-Tazz," Iowa City Oppressed Citizen, February 1971, Underground Publications, University of Iowa Special Collections. 
if our righteous youth nation was a reality. But so far it's only a slogan, only a dream. We're going to have to build it. And we're going to have to put a lot of love and warmth and concern in it. We aren't together. Not yet. If we can't tear down the walls that divide us, if we can't start being more open and loving to our sisters and brothers, if we can't relate to both Hendrix and the 12-year-old teeny bopper, if we can't stop smack ... then the culture isn't worth much. Goodbye Jimi. Thanks for the good times.

Those who previously believed in the power of music in the youth revolution slowly began to realize the destruction that the combination of drugs and music wrought. Those who founded the movement blamed themselves for the deaths or displacements of teenagers and runaways who had escaped to become part of the hip music scene, only to find that the hippies had lost their way somewhere down the road of hard drugs and revolution.

The tensions between audiences and musicians that began at the Isle of Wight Festival in 1969 also contributed to the death of the folk and psychedelic movements. By 1971, most of the original avant-garde community that had believed in music as a form of free expression saw through the capitalistic ventures of record companies and executives. In November of 1970, the Oppressed Citizen published a comic entitled “Far Out' Filbert, the Hip Capitalist." The copy read:

Once upon a time, in a place not so very far away, all of the children of the great, powerful nation woke up to the fact that their parents' way of life disgusted them, because all anybody ever thought of was how to make money! So... the kids dropped out of the belly of the monster-culture and said that they would lead lives of PEACE and LOVE and they could listen to MUSIC and DO THEIR THINGS... 'Far Out' Filbert organized a huge ROCK FESTIVAL and told all of the kids to come and hear ROCK and ROLL and smoke DOPE and have PEACE and LOVE...But they had to wait for 3 days to use a bathroom, and PIGS were at the rock festival and hit them on the heads and BUSTED them for smoking dope! All of a sudden, someone noticed 'Far-Out' Filbert escaping from the rock festival with a big bag of MONEY! The kids descended upon 'FarOut' Filbert and beat the living shit out of him! The kids realized that the capitalism-monster could follow them wherever they went 
and that they could not be free until it had been DESTROYED! Right on, kids!133

This cartoon was mirrored in an accompanying article, "Rock Rip Offs," which lamented, "Yet even though rock music comes from us and is directed toward us, it is totally out of our control. The production and presentation of the music cannot be separated from the capitalist system and the system is messing over the music." ${ }^{134}$ By 1971, many of the psychedelic and blues groups, including Linn County and the Mother Blues Band, either split up or left Iowa City. A few young men began broadcasting an independent rock radio show out of their dorm room in order to combat the commercial stations and their "sellout" disc-jockeys. ${ }^{135}$ In its penultimate issue, the Oppressed Citizen wrote, "We chose to build and protect our Woodstock Nation while dancing to the death tune of a dying America." 136 As the force behind student protest died out, so too did the hope for the Woodstock Nation. Many musicians and artists that were present within the scene during its heyday chose to drop out of school, Iowa City, and society altogether.

\section{When the Ship Comes In: The Legacy of Iowa Student Protest}

And the words that are used

For to get the ship confused

Will not be understood as they're spoken.

For the chains of the sea

Will have busted in the night,

And will be buried at the bottom of the ocean.

A song will lift

As the mainsail shifts,

And the boat drifts on to the shoreline.

And the sun will respect

133 “"Far-Out' Filbert, the Hip Capitalist," Iowa City Oppressed Citizen, November 1970, Underground Publications, University of Iowa Special Collections.

134 “Rock Rip Offs," Iowa City Oppressed Citizen, November 1970, Underground Publications, University of Iowa Special Collections.

135 "Underground FM Station," The Daily Iowan, December 15, 1971, University of Iowa Digital Collection.

${ }^{136}$ Iowa City Oppressed Citizen, February 1971, Underground Publications, University of Iowa Special Collections. 
Every face on the deck

The hour that the ship comes in.

\section{When the Ship Comes In, Bob Dylan 1964}

This sentiment by Dylan reflects the hope of the student protest movement from its early conception: that the chains of oppression "will have busted in the night" and that the sun, meaning society, "will respect every face on the deck" regardless of color, sex, religion, economic standing, or sexual orientation. Since the Iowa protest movement ended in 1971, we have come a long way in recognizing and achieving that dream. However, many of the remaining members of the student movement do not see this as far enough. "Unfortunately, I don't know that much has changed," says Fred Walk. "Police brutality is still out here, corruption, segregation - they still exist. I think things are getting better, but things shouldn't have taken this long. There's a god damn long way to go." 137 The fact that widespread oppression, racism, sexism, and basic discrimination still exists leads to the question: What did the student movement actually accomplish?

It is extreme to say that the student movement ended the draft or the Vietnam War. While anti-draft and anti-war sentiment did help pressure the abolition of the draft, it also instigated the "silent majority" of Americans to loathe and, ultimately, expel the student protestors. "I think we were on the verge of a revolution," Diane Troyer says, "but when Charlie Manson killed those girls [in 1969] it made everybody stop and think about just how horrible blood really is, and that really killed a revolution." 138 Manson's actions, driven by a crazed interpretation of the White Album, turned many to question the harmlessness of the counterculture.

Simultaneously, the militant, sometimes violent, actions of extremists within the student movement poisoned it from the inside-out. Unfortunately, much of this militant action was spurred completely in opposition to military authority, instead of in solidarity with those sharing a common political message. Conventional memory pins the blame on these protestors, but Patrick Hazell speaks from a different perspective: "These violent techniques- the cops just kept going, not realizing that if they had just kept their cool it all

\footnotetext{
137 Walk interview.

138 Troyer interview.
} 
would have fizzled out. It really would have." 139 Thus, it is important to put contemporary memory of the student protests at the University of Iowa into perspective. The violent confrontation that characterized the protests in 1970 and 1971 cannot be blamed entirely on the student movement, the militant faction of this movement, or the police forces. Rather, it was national and local tensions between the three that had been brewing since 1967 that led to such confrontation, and it was these same tensions that poisoned the movement in the end.

To many activists, artists, and musicians, the takeaway was that they had made their voices heard. The activists raised new questions about the rights of students, the role of the university, the scope of authority, local racism and sexism, and the morality of violence. "People came to Iowa City just to be part of that movement that was happening all over the world," Patrick Hazell remembers. "Iowa City was an important part of that scene, I think." 140 In Iowa City, activists and artists created a community that stood for an alternative version of what society could be: the People's Revolution, the Woodstock Nation. Many, like Diane Troyer, felt that their art was how they gave themselves to the cause. As such, their art and efforts not only defined their political movement, but also impacted their local community and their individual lives. 'Larry [Diane's husband] grabbed me and held me. He said, 'Okay. If I'm killed, you do something about it. YOU.' I tried to call people. I tried to do something. But, what can you do? All I could do was express my art—make that film. And that's what I've been doing my whole life."141

The art and music of these activists still survives today. It will still survive when its creators have passed. It will still survive when the commonplace memory of the events it informed has disappeared. It can transcend its own place and time, and perhaps inform the struggles of activists in future generations. This is best expressed in the lyrics of the song "Gracious Sir" by local musician Jay Stein. The song is featured in the last moments of Coover's film On a Confrontation in Iowa City. As the picture fades away, the voice, accompanied by guitar, remains steady, honest, and resolute:

Well I know it's good for business,

But I know it's wrong for man.

That's why I must oppose you

\footnotetext{
${ }^{139}$ Hazell interview.

140 Ibid.

141 Troyer interview.
} 
In every way I can.

Well I know you've got the guns and clubs

To beat me to the ground.

But I hope you know

That even so,

I'll always be around. ${ }^{142}$

\section{Bibliography}

Crosby, Stills, Nash, and Young. Obio. CD. New York: Atlantic Records, 1970.

The Daily Iowan, 1868-Present. Student Protest Vertical File, University of Iowa Special Collections.

Des Moines Register, 1902-Present. Student Protest Vertical File, University of Iowa Special Collections.

Diane Troyer. Interview by Taylor Finch. Iowa City, IA. September 25th, 2015.

Finley, Mike. "From the Right." In Iowa '70: Riot, Rhetoric, Responsibility? Edited by James H. Potter. 1970. Student Protest Vertical File, University of Iowa Special Collections.

Foley, Michael S. Confronting the War Macbine: Draft Resistance During the Vietnam War. Chapel Hill, North Carolina: University of North Carolina Press, 2003.

Fred Walk. Interview by Taylor Finch. Iowa City, IA. August 31, 2015.

Georgetown University SDS. "View from the Outside." In V andals in the Bomb Factory: The History and Literature of the Students for a Democratic Society, edited by Louis G. Heath. New Jersey: Scarecrow Press, 1976.

The History of Rock N'Roll. Directed by Andrew Solt. 1995. Burbank, CA: Time-Life Video, 2004. DVD.

Iowa City Oppressed Citizen, 1970-71. Student Protest Vertical File, University of Iowa Special Collections.

Iowa City Press Citizen, 1920-Present. Student Protest Vertical File, University of Iowa Special Collections.

Kelman, Steven. Push Comes to Shove: The Escalation of Student Protest. Boston: Houghton Mifflin Company, 1970.

McCartney, David. “Old Gold: Steve Smith, following his conscience.” Iowa Now, July 30, 2012. Accessed October 3, 2015. http://now.uiowa.edu/2012/07/old-goldsteve-smith-following-his-conscience.

Middle Earth, 1967. Underground Publications, University of Iowa Special Collections.

${ }^{142}$ Coover, On a Confrontation in Iowa City.

http://ir.uiowa.edu/iowa-historical-review 
Ochs, Phil. I Ain't Marching Anymore. CD. London: Elektra Records, 1965.

Ochs, Phil. Love Me, I'm a Liberal. CD. London: Elektra Records, 1966.

Ohio State Students for a Democratic Society. "Let the Voice of the People Be Heard." In V andals in the Bomb Factory: The History and Literature of the Students for a Democratic Society, edited by Louis G. Heath. New Jersey: Scarecrow Press, 1976.

On a Confrontation in Iowa City. Directed by Robert Coover. 1969. Iowa City, IA: University of Iowa Libraries, 2015. Streaming Video.

Oppenheimer, Martin. "How We Found Out About COINTELPRO." Monthly Review: An Independent Socialist Magazine 66, no. 4 (September 2014): 54-60.

Patrick Hazell. Interview by Taylor Finch. Washington, IA. April 25 ${ }^{\text {th }}, 2015$.

Pearsons, Stow. The University of Iowa in the Twentieth Century: An Institutional History. Iowa City: University of Iowa Press, 1990.

"The Port Huron Statement." In Vandals in the Bomb Factory: The History and Literature of the Students for a Democratic Society, edited by Louis G. Heath. New Jersey: Scarecrow Press, 1976.

Selective Service Act of 1948, 50 U.S.C. \ 451-473 (1948).

University of Chicago SDS. "Women, Rise Up!" In V andals in the Bomb Factory: The History and Literature of the Students for a Democratic Society, edited by Louis G. Heath. New Jersey: Scarecrow Press, 1976. 